Nilson Vieira Ferreira de Mello Junior

\title{
POLÍTICA E DIREITO NA FILOSOFIA CONVERGENTE DE NORBERTO BOBBIO
}

Dissertação de Mestrado

Dissertação apresentada ao Programa de PósGraduação em Filosofia da PUC-Rio como requisito parcial para a obtenção do grau de Mestre em Filosofia.

Orientador: Prof. Edgard José Jorge Filho

Rio de Janeiro

Fevereiro de 2018 


\title{
POLÍTICA E DIREITO NA FILOSOFIA CONVERGENTE DE NORBERTO BOBBIO
}

\begin{abstract}
Dissertação apresentada ao Programa de Pós-Graduação em Filosofia da PUC-Rio como requisito parcial para a obtenção do grau de Mestre em Filosofia. Aprovada pela Comissão Examinadora Abaixo Assinada.
\end{abstract}

Prof. Edgard José Jorge Filho

Orientador

Departamento de Filosofia - PUC-Rio

Prof. Maxime Rovère Departamento de Filosofia PUC-Rio

Prof. Adilson Rodrigues Pires

UERJ

Profa. Monah Winograd

Coordenadora Setorial de Pós-Graduação e Pesquisa do Centro de

Teologia e Ciências Humanas - PUC-Rio

Rio de Janeiro, 26 de fevereiro de 2018 
Todos os direitos reservados. É proibida a reprodução total ou parcial do trabalho sem autorização da universidade, do autor e do orientador.

\section{Nilson Vieira Ferreira de Mello Junior}

Graduou-se em Jornalismo (Comunicação Social) e em Direito pela PUCRio, respectivamente, em 1989 e em 2000. É pós-graduado em Economia (especialização em Análise Conjuntural), pela UFRJ, e em Direito (especialização em Direito Tributário), pela FGV-Rio. Integra a Comissão de Filosofia do Direito e de Direito Financeiro e Tributário do IAB Instituto dos Advogados Brasileiros. É autor de Brasil tão bom quanto o nosso voto - Ensaios e artigos sobre Estado, Governo e Sociedade. Atuou como jornalista por mais de 10 anos em diferentes órgãos da imprensa. Atua desde 1999 como consultor nas áreas de Relações Institucionais, Assessoria Política e Comunicação Corporativa e, desde 2005, também como advogado. É sócio-fundador do Ferreira de Mello Advocacia e da Meta Consultoria e Comunicação Ltda.

Ficha Catalográfica

Mello Junior, Nilson Vieira Ferreira de

Política e direito na filosofia convergente de Norberto Bobbio / Nilson Vieira Ferreira de Mello Junior ; orientador: Edgard José Jorge Filho. 2018.

89 f. ; $30 \mathrm{~cm}$

Dissertação (mestrado)-Pontifícia Universidade Católica do Rio de Janeiro, Departamento de Filosofia, 2018.

Inclui bibliografia

1. Filosofia - Teses. 2. Norberto Bobbio. 3. Política. 4. Direito. I. Jorge Filho, Edgard José. II. Pontifícia Universidade Católica do Rio de Janeiro. Departamento de Filosofia. III. Título.

CDD: 100 


\section{Agradecimentos}

Ao professor Edgard José, meu orientador, pelo cordial apoio e pelas pertinentes recomendações e correções sem as quais este trabalho não seria possível.

À professora Vera Cristina Bueno, cujas palavras incentivadoras foram o ponto de partida de meu Mestrado.

À minha mulher, Lilita, aos meus filhos, João e Pedro, e aos meus pais, Maria Luiza e Nilson, pelo carinho e o apoio, desde sempre.

A todos os professores e funcionários do Departamento de Filosofia da PUC-Rio, pelas indispensáveis orientações.

À CAPES, pelo auxílio concedido para a realização deste Mestrado.

À PUC-Rio, pela oportunidade de cursar este Mestrado. 


\section{Resumo}

Mello Junior, Nilson Vieira Ferreira de; Jorge Filho, Edgard José. Política e Direito na Filosofia Convergente de Norberto Bobbio. Rio de Janeiro, 2018. 89p. Dissertação de Mestrado - Departamento de Filosofia, Pontifícia Universidade Católica do Rio de Janeiro.

Não há política sem direito e nem direito sem política. A relação de interdependência deve-se estabelecer tendo em vista a justiça. E é a razão que deve estruturar o direito visando o exercício da política, em nome da justiça. São essas interseções que emergem da obra de Norberto Bobbio, formando o pano de fundo de suas reflexões. Neste sentido, o seu pensamento é duplamente convergente. Primeiramente, porque busca, de forma permanente, a ligação entre direito e política, examinando as suas fundamentações e influências recíprocas. Em segundo lugar porque constroi, com espírito conciliador e reformador, o diálogo entre campos ideológicos opostos. Um diálogo estabelecido com base na razão, que, por sua vez, deve convergir em direção à justiça. A sua obra nos campos da Filosofia Política, da Filosofia do Direito e da Teoria do Estado inserese num período de forte polarização da Europa no pós-Segunda Guerra. O filósofo e jurista italiano esteve entre os mais importantes interlocutores dos embates travados no século XX. Sua fecunda produção intelectual, de notável abrangência, constitui uma ferramenta segura para a análise isenta dos acontecimentos políticos no mundo contemporâneo.

\section{Palavras-chave}

Norberto Bobbio; Política e Direito; Governo; Estado e Sociedade; Formas de Governo; Positivismo e Jusnaturalismo. 


\section{Abstract}

Mello Junior, Nilson Vieira Ferreira de; Jorge Filho, Edgard José (Advisor). Politics and Law in the Convergent Philosophy of Norberto Bobb. Rio de Janeiro, 2018. 89p. Dissertação de Mestrado - Departamento de Filosofia, Pontifícia Universidade Católica do Rio de Janeiro.

There can be no politics without law and no law without politics. The interdependent relationship of these two concepts must be established with Justice as its goal. Reason must shape law for the exercise of politics in the name of Justice. These are the elements that continually intersect in the works of Noberto Bobio and form the background of his thinking. Thus, his thoughts are doubly convergent. Firstly, because they seek a permanent link between Politics and Law, and secondly, because they attempt, both in a conciliatory and reforming manner, to pave the way for a dialogue between opposing ideological camps, a dialogue based on reason pointed in the direction of Justice. Bobio's works in the fields of Political Philosophy, The Philosophy of Law and the Theory of State emerged during a period of intense polarization in Europe after the Second World War. He was at the forefront of the most important debates on these matters that took place during the XX Century. Bobio's profound intelectual production, noteworthy for its all embracing scope, is certainly a dependable instrument for analyzing the political events in the world today.

\section{Keywords}

Politics; Law; Bobbio. 


\section{Sumário}

1. Introdução 8

2. O Pensamento político - Uma questão de justiça 15

3. O exame das formas de governo 31

4.O Pensamento jurídico - A estruturação do poder 46

5. Positivismo e Jusnaturalismo - Uma questão de direito 58

6. A Era dos Direitos 70

$\begin{array}{ll}\text { 7.Considerações Finais } & 81\end{array}$

8. Referências bibliográficas $\quad 87$ 


\section{Introdução}

A presente dissertação oferece um mosaico do pensamento de Norberto Bobbio, enfatizando aspectos capitais de sua obra. Há razões acadêmicas consistentes para a escolha de Bobbio como tema para uma dissertação de mestrado em Filosofia Política. Podem-se salientar, entre as muitas, o fato de o filósofo e jurista italiano ter estado entre os mais importantes interlocutores dos embates ideológicos travados na Europa do século XX. Acrescente-se a esse aspecto a sua fecunda produção intelectual, de notável abrangência. Ressalte-se, ainda, o seu caráter conciliador, algo que o coloca em posição de destaque entre os mais importantes intelectuais e acadêmicos de seu tempo.

Na sua produção intelectual, na sua prática acadêmica e na sua atividade política, procurou sempre exercer uma função mediadora, buscando a convergência não apenas entre as suas áreas de estudo - em especial, o direito e a política - como entre correntes ideológicas opostas, para as quais pavimentou o diálogo, disseminado a tolerância. É Carlo Violi quem bem salienta essa sua característica, no comentário que serve de Introdução a Nem com Marx, nem contra Marx. ${ }^{1}$ Afirma Violi:

"Naquela situação conflituosa determinada pela contraposicão dos blocos, não estava de modo algum afastado o perigo de uma terceira guerra mundial e do choque frontal entre capitalismo e comunismo. No clima de 'guerra fria' e das ideologias em contraste, Bobbio assumiu a função do intelectual 'mediador', cujo dever era essencialmente o de lançar uma ponte sobre o abismo que então dividia os intelectuais de formação liberal e os intelectuais comunistas, restabelecendo assim a confiança no diálogo entre as partes em conflito". ${ }^{2}$

Bobbio é definido por muitos de seus comentaristas como um neoiluminista. Um filósofo do direito e da política que defendeu princípios da tradição liberal recusados, no seu tempo, pelos marxistas, que os viam, conforme salienta $\mathrm{Violi}^{3}$, como "expressão da ideologia burguesa e não como valores humanos dignos de ser garantidos a todos os cidadãos". A prática política e acadêmica de Bobbio estaria assim voltada para conjugar liberalismo e

\footnotetext{
${ }^{1}$ BOBBIO, Norberto. Nem com Marx, nem contra Marx. São Paulo-SP, Editora UNESP, 2004.

${ }^{2}$ Obra cit., pág. 14.

${ }^{3}$ Obra cit., pág. 15.
} 
socialismo, promovendo uma integração dos direitos de liberdade com as exigências de justiça social, dois princípios indispensáveis para que uma democracia seja substancial, e não apenas formal.

O pensador de Turim não deixou uma escola filosófica propriamente dita, como aponta Giuseppe Tosi ${ }^{4}$, no sentido de um grupo homogêneo de seguidores e discípulos com uma orientação comum, mas formou pensadores "da mais alta qualidade", conforme lembra o próprio Tosi.

Os estudos desenvolvidos por Norberto Bobbio ao longo de seus 78 anos de intensa atividade intelectual (de vida, foram nove décadas e meia) abrangeram, com profundidade, os campos da Filosofia Política e da Ciência Política, bem como o da Filosofia do Direito e o da Teoria do Estado. Concisão foi uma de suas principais características, o que não significa, de forma alguma, que sua obra esteja condensada em poucos volumes. Ao contrário, seus biógrafos contabilizam mais de 4.803 escritos catalogados, dos quais 128 livros, 944 artigos, 1.452 ensaios, 457 entrevistas e 316 conferências ${ }^{5}$. Ao lado de Gramsci o autor italiano mais traduzido, Bobbio obteve um sucesso editorial pouco comum a autores acadêmicos.

Grande parte de seus livros é uma coletânea de artigos, cursos e conferências, e uma das características dessa vasta obra é a "assistemacidade" - o que talvez possa explicar em parte o fato de não ter dado origem a uma escola filosófica. Afirma Marco Ravelli, citado por Tosi:

"Não pode ser descuidado o caráter, de alguma forma assistemático da obra bobbiana, declaradamente desprovida, por afirmação explícita do seu criador, de um único e bem reconhecível fio condutor unitário, ou de um plano conscientemente perseguido durante o percurso inteiro [...] Perguntado sobre a existência de um fio condutor que perpassasse toda a sua obra, Bobbio declarava que: 'este fio vermelho provavelmente não existe'. E confessava que 'esses escritos são fragmentos de vários desenhos que não podem ser sobrepostos uns aos outros, e cada um é inconcluso' ". 6

Mas, para o filósofo político, a Teoria Geral do Direito é importante na medida em que tem a função de fixar as condições de juridicidade dos institutos jurídicos, como veremos mais detalhadamente no Capítulo 5. Esse talvez tenha sido o fio condutor e integrador que Bobbio não reconheceu à sua obra

\footnotetext{
${ }^{4}$ TOSI, Giuseppe. 10 Lições sobre Bobbio. São Paulo (SP), Editora Vozes, 2016,p. 24.

${ }^{5}$ Obra cit., pag. 25.

${ }^{6}$ Obra cit., pag. 29.
} 
De qualquer forma, a assistemacidade de sua obra, somada à abrangência e a inexistência de uma "escola bobbiana", faz com que um trabalho sobre Bobbio seja mais de caráter descritivo do que propriamente analítico. A exemplo dos textos produzidos por seus muitos comentaristas, a presente dissertação não foge à regra, ainda que tentando acrescentar análises pontuais e comparativas à exposição realizada.

Da leitura dos escritos de Bobbio percebe-se uma busca incessante pela clareza conceitual, tarefa realizada a partir de aproximações sucessivas e do estabelecimento de dicotomias. Seu pensamento emerge de forma simples, porém, com absoluto rigor científico e intuitivo. Comentaristas como Lafer, Santillán e Tosi exaltam a sua erudição e o seu classicismo. Entre suas principais obras publicadas, devemos citar Estado, Governo e Sociedade - Para um teoria geral da política, Teoria das Formas de Governo, Teoria do Ordenamento Jurídico, Teoria da Norma Jurídica, Dicionário de Política (escrito em conjunto com Nicola Mattenti e Gianfanco Pasquino), Igualdade e Liberdade, $O$ Positivismo Jurídico, Direito e Estado no Pensamento de Immanuel Kant, Ensaios sobre Gramsci, Direito e Poder e Nem com Marx, nem contra Marx.

São também seus comentadores que classificam seus escritos em quatro grandes grupos: 1) Tratados de filosofia e história do direito e da política, nos quais tenta definir e organizar os principais conceitos de uma teoria geral da política e do direito; 2) Apostilas dos cursos universitários, dedicados à lição dos clássicos, em especial do pensamento político e jurídico moderno, como Hobbes, Locke, Rousseau, Kant e Hegel; 3) Ensaios dedicados a figuras relevantes da filosofia política e do direito no século $\mathrm{XX}$, alguns dos quais considera seus mestres, como Giole Solari, Benedetto Croce, Hans Kelsen e Max Weber; 4) Ensaios sobre o debate político atual em torno de temas como marxismo, democracia, paz, direitos humanos, liberalismo, relação entre ética e política e pacifismo.

Paz e liberdade são temas recorrentes no pensamento de Bobbio. Não por outra razão, Kant é uma de suas principais referências. Bobbio confia na possibilidade reformista que está ao alcance da razão. Se a guerra interna era um problema crucial para Hobbes, será, por sua vez, a guerra externa que mobilizará o intelecto convergente e pacificador de pensador italiano. Pacificador no sentido de ter emprestado a sua capacidade intelectual para a mediação entre opostos. 
Nos passos kantianos, portanto, Bobbio entende que a eliminação da guerra dependerá de um "pacto social" em escala global. Para um teórico do direito e da política, como ele, a guerra não pode ser vista de outra forma senão como sendo a "antítese do próprio direito", conforme assinala Celso Lafer ${ }^{7}$. Ainda que ela possa ser ética - como, por exemplo, a guerra contra o nazismo e o fascismo, da qual ele tomou parte -, significa que em algum momento o direito fracassou.

Se poder e norma (no sentido jurídico) são faces da mesma moeda, deverá sempre haver, segundo o pensamento bobbiano, uma convergência substantiva entre filosofia e política, ou, como ressalta Lafer, a teoria do direito deverá sempre requerer, se seguirmos as lições de Bobbio, uma teoria do estado. O pensamento de Bobbio é, assim, duplamente convergente. No primeiro sentido, mais estrito, à medida que as suas formulações procuram fomentar a conciliação, a partir de um diálogo pautado pela razão. Foi o que ele fez na prática ao longo de sua vida acadêmica e na prática da atividade política. Não sendo de forma alguma um filósofo da ruptura, mas, sim, um pensador que acreditava no contínuo aperfeiçoamento do sistema (a humanidade em progresso para o melhor), manifestava o seu horror a posições extremistas, sobretudo quando elas glorificam a violência.

Na opinião de Tosi, o seu "moderatismo" nasce da opção pelo diálogo, pela confrontação de opiniões, pela mediação, pelo pluralismo contra os dogmatismos e fanatismos ideológicos. Tosi reproduz uma declaração de Bobbio que sintetiza essa ideia:

"Da observação da irredutibilidade das crenças últimas extraí a maior lição de minha vida. Aprendi a respeitar ideias alheias, a deter-me diante do segredo de cada consciência, a compreender antes de discutir, a discutir antes de condenar. E porque estou com disposição para as confissões, faço mais uma ainda, talvez supérflua: detesto os fanáticos com todas as minhas forças". 8

No segundo sentido, o seu pensamento é também convergente, porque, como mencionado acima, busca compatibilizar política e direito, e vice-versa. $\mathrm{Na}$ tentativa de compatibilização, o Estado deve estar a serviço da justiça - jamais o inverso. Uma ideia que se opõe frontalmente a qualquer tentativa de totalitarismo.

\footnotetext{
${ }^{7}$ LAFER, Celso. Norberto Bobbio: Trajetória e Obra. São Paulo (SP), Editora Perspectiva, 2013.

${ }^{8}$ TOSI, Giuseppe. 10 Lições sobre Bobbio. São Paulo (SP), Editora Vozes, 2016, pag. 35.
} 
Bobbio nasceu em Turim em 1909, capital do Piemonte, na Itália, cidade em que também veio a falecer em 2004. Filho de um médico cirurgião, teve uma educação liberal. Disse ele, certa vez: "Em minha família nunca tive a impressão de conflito de classes. Fomos educados a considerar todos os homens iguais. E recordei esta educação para um estilo de vida democrático". Mais tarde, iria reconhecer que o estilo de vida de sua família era o que, na Itália da primeira metade do século passado, poderia ser considerado um "filo-fascismo familiar". Recebeu uma educação liberal, no sentido político do termo. De berço "burguês", foi, sempre, um forte defensor da pluralidade do pensamento e, mais que isso, um grande oponente do fascismo. Chegou a ser preso na década de 1930, recebendo pena de advertência, quando rebelou-se contra as primeiras leis fascistas do regime de Mussolini, e novamente em 1943, nos estertores do regime.

Graduou-se na Faculdade de Jurisprudência de Turim, em 1927. Sete anos mais tarde, já assumia um posto de docente na Universidade de Camerino. Integrou o movimento Socialista-Liberal na década de 1930 - uma rede de oposição ao regime mussoliniano, que reunia acadêmicos, associações religiosas e organismos culturais. Também denominado "Degelo de Consciência", esse foi o primeiro movimento da juventude intelectual de inspiração não-marxista contra o governo fascista.

Em 1948, após a Segunda Guerra, volta para a Turim natal, onde passa a lecionar não apenas Filosofia do Direito como Filosofia Política. Mais tarde, ministra também aulas específicas de Ciência Política. Exprime, desde os primeiros anos de docência, a dupla e convergente paixão pelo Direito e pela Filosofia. Foi profundo conhecedor de Grotius, Spinoza, Locke, Kant, Rousseau, Hegel e Weber, sofrendo influência de todos eles.

Em 1979, para de lecionar, mas mantém intensa atividade publicando livros, ensaios e artigos, e participando do debate político italiano. Em 1984, é nomeado senador vitalício pelo presidente Sandro Pertini. Fez ao longo de sua vida a defesa das regras do jogo democrático, a partir dos seguintes valores: sociedade livre, tolerante, laica e plural. Foi um pensador agnóstico sem ser anticlerical. Seu laicismo deve ser entendido tanto do ponto de vista religioso quanto ético-político.

A sua obra encontra-se na confluência das três grandes correntes ideológicas do século passado: o comunismo, o fascismo (e, por extensão, o 
nazismo) e o liberalismo democrático com suas várias nuances, representadas e sob a vigorosa influência, na conjuntura política italiana de seus primeiros anos na Academia, respectivamente, por Antonio Gramsci (1891-1937), Giovanne Gentile (1875-1944) e Beneditto Croce (1866-1952). Ao se opor a Mussolini, rejeita Gentile intelectualmente e se coloca como síntese entre os outros dois pensadores contemporâneos e conterrâneos. Afirmava que havia, a rigor, dois tipos de intelectuais: o ideológico e o puro. Para o primeiro, a verdade era aquela que servia à revolução; para o segundo, a verdade era por si só revolucionária. Mas, se por um lado critica a identificação do compromisso político e do compromisso cultural inerente aos ideológicos (ou "orgânicos"), também reprovava os puros, que se colocam como clérigos, apartados da sociedade. Propõe uma autonomia relativa para o intelectual, como forma de superar esses dois extremos.

No campo jurídico, Bobbio é um positivista legal ou, como prefere Celso Lafer ${ }^{9}$, um normativista. Difere de Hans Kelsen ${ }^{10}$, porém, porque, ao contrário deste, não reduz o Estado ao Ordenamento Jurídico. Se para o positivista alemão a distinção entre Direito Público e Direito Privado é ideológica, para Bobbio ela é sobretudo científica. Como Max Weber ${ }^{11}$, incorpora, em suas análises, o ponto de vista jurídico e o ponto de vista sociológico. Pode-se dizer que, em certo sentido, é um pós-naturalista como Hegel, ou seja, vislumbra e reconhece outras dimensões para o Estado além daquela restrita à fundação que the atribui o Contrato Social hobbesiano.

Enfrenta em seus ensaios, desde o início, os principais questionamentos dos postulados teóricos do debate filosófico, tais como liberdade, igualdade, tolerância, pluralismo. No direito, seus estudos enquadram-se em três campos. O primeiro, o ontológico, ou seja, o da Teoria do Direito que se ocupa com o direito como esse existe, procurando alcançar uma compreensão "consensualizada" da Ciência Jurídica, da Sociologia Jurídica e da História do Direito; o segundo seria o Metodológico, que foca o estudo dos procedimentos lógicos usados na argumentação jurídica e na aplicação do direito; e, por fim, um terceiro campo de estudo filosófico do direito em que busca uma análise com valoração ideológica

\footnotetext{
${ }^{9}$ BOBBIO, Norberto. A Teoria das Formas de Governo. Brasília (DF), Editora Universidade de Brasília, 10a Edição (Prefácio)

${ }^{10}$ KELSEN, Hans. O Positivismo Jurídico. São Paulo-SP, Martins Fontes, 1999.

${ }^{11}$ WEBER, Max. Ciência e Política. São Paulo-Sp, Ed. Cultrix, 1993
} 
da interpretação e aplicação das normas jurídicas, ou seja, incorporando uma crítica ao direito positivo.

Como salienta Lafer $^{12}$, para Bobbio o problema principal da Teoria do Direito é a determinação do conceito de direito e a diferenciação do fenômeno jurídico de outros fenômenos, como a moral e os costumes. Bobbi vê, portanto, o direito como um conjunto de normas a serem estudadas sistematicamente por meio do conceito de ordenamento jurídico, compreendendo: 1. a composição (conceito de normas e seus vários tipos); 2. a formação (a teoria das fontes do direito); 3. a unidade do ordenamento (ou seja, a questão da hierarquia das normas); 4. a inteireza (ou seja, a integração das lacunas); 5. a coerência (o problema das antinomias); 6. as relações espaciais, materiais e temporais derivadas do inter-relacionamento do ordenamento.

Na visão de Bobbio, existem três pontos de vista a partir dos quais se pode avaliar uma norma: o da justiça; o da validade; e o da eficácia. Daí porque a experiência jurídica deve levar em conta as ideias de justiça a se realizar e as normas que exprimem a reação dos homens a essas ideias. $\mathrm{O}$ normativismo de Bobbio não exclui a Filosofia do Direito, ou seja, a lei positiva não é justa pelo simples fato de ser Lei e resultar de uma convenção. E é por esta razão que a sua Teoria do Direito exige uma Teoria da Justiça, com abordagem necessariamente filosófica.

A sua Teoria da Justiça requer uma reflexão não apenas analítica - daquela do tipo feita por Kelsen ou Perelman ${ }^{13}$ - mas também um estudo que passe igualmente pela história do direito e considere uma investigação axiológica (de valor moral) e sociológico. Por essa razão, para alguns comentaristas, Bobbio seria um historicista que combina a deontologia (estudo daquilo que o Direito deve ser) com a sociologia jurídica, ou seja, a evolução do direito na sociedade e as relações do direito com a sociedade e o indivíduo. O critério que deve orientar o estudo do direito, segundo ele, é o conceito de justiça, entendido como um conjunto de valores e interesses cuja proteção interessa, de forma nem sempre consensual, aos indivíduos de uma sociedade.

\footnotetext{
${ }^{12}$ BOBBIO, Norberto. A Teoria das Formas de Governo. Brasília (DF), Editora Universidade de Brasília, 10a Edição, pág. 13.

${ }^{13}$ PERELMAN, Chaïm. Ética e Direito. São Paulo-SP, Martins Fontes, 1999.
} 


\section{O Pensamento político - Uma questão de justiça}

Na confluência de política e direito e, por desdobramento, na dissecação do conceito e das ideias de poder, Bobbio torna-se uma bússola para a interpretação de textos clássicos da Filosofia Política. Obras como Teoria das Formas de Governo e Estado, Governo e Sociedade - para uma teoria geral da política nos permitem o resgate desses textos clássicos, com o rigor analítico que a pesquisa acadêmica exige.

A convergência entre Filosofia Política e Filosofia do Direito implica uma discussão acerca do inter-relacionamento entre direito e poder. No campo político, Bobbio propugna um socialismo não-marxista e, portanto, democrático, tanto no sentido formalista quanto substancial do termo, distante da "ditadura do proletariado". Rejeita a confusão entre partido político e movimento social, assim como qualquer forma de reducionismo político, o que faz com que seja contrário à absolutização da política. Seu "socialismo-liberal" é mais uma atitude de espírito do que uma ação partidária. $\mathrm{O}$ direito tem então, na sua visão, uma função primordial na democracia, como "técnica de convivência indispensável para a reforma da sociedade", como aponta Lafer. ${ }^{14}$

Afirma Bobbio em Estado, Governo, Sociedade - Para um teoria geral da política, em uma passagem que constitui um preciso diagnóstico dos conflitos que levam à instabilidade política em qualquer nação:

"Uma sociedade torna-se tanto mais ingovernável quanto mais aumentam as demandas da sociedade civil sem que aumente, correspondentemente, a capacidade das instituições oficiais de a elas responder, ou melhor, com a capacidade de resposta do Estado alcançando limites talvez não mais superáveis (donde o tema, por exemplo, da "crise fiscal"). A ingovernabilidade gera crise de legitimidade" 15 .

Em Estado, Governo, Sociedade, obra didática que é ao mesmo tempo descritiva e analítica, o pensador de Turim expõe em quatro capítulos temas cruciais para a compreensão e estruturação dos conceitos de política, poder e

\footnotetext{
${ }^{14}$ Obra cit, pag. 194.

15 BOBBIO, Norberto. Estado, Governo e Sociedade - Para uma teoria geral da Política. São Paulo (SP), Paz e Terra, 1997/6a Edição, pag. 36
} 
Estado. São eles: I. A Grande dicotomia: público/privado; II. A sociedade civil; III. Estado, Poder e Governo; e IV. Democracia e Ditadura.

Em relação ao primeiro tema, ensina Bobbio que há três distinções que dominam o debate acerca da dicotomia público-privado. A primeira diz respeito ao confronto entre sociedade de iguais e sociedade de desiguais. A segunda detém-se no exame da Lei, ou seja Lex, Direito Público propriamente dito, e Contrato, o direito privado em espécie. E a terceira volta-se para a contraposição entre justiça comutativa e justiça distributiva. O enfrentamento da dicotomia requer o emprego das três dimensões.

Salienta que, na linguagem jurídica, a preeminência da distinção entre direito privado e direito público sobre todas as outras distinções chegou a ser de tal ordem que alguns filósofos passaram a considerar esses conceitos como duas categorias a priori do pensamento jurídico. Os dois termos podem ser considerados de forma independente ou isoladamente, quando apenas um é definido e outro ganha, de forma indireta, uma definição negativa. Também é correto dizer que ambos condicionam-se reciprocamente, no sentido que se reclamam continuamente um ao outro. Escreve Bobbio:

"Um dos lugares-comuns do secular debate sobre a relação entre esfera do público e a do privado é que, aumentando a esfera do público, diminui a do privado, e aumentando a esfera do privado diminui a do público, uma constatação que é geralmente acompanhada e complicada por juízos de valores contrapostos". ${ }^{16}$

Neste sentido, não se deve esquecer a célebre distinção de Cícero de res publica, segundo a qual essa é uma "coisa do povo", entendido aqui não como uma agregação de homens, mas uma sociedade mantida junta, mais do que por vínculo jurídico, por interesses comuns ou recíprocos. Para a Dicotomia tradicional entre Público e Privado, convergem outras complementares e acessórias, estruturadas ao longo da história das Ciências Sociais. Assim temos, como primeira duplicação, as sociedades de iguais e as sociedades de desiguais; a sociedade de detentores do poder e de destinatários do poder, ou seja, agentes do dever de obediência, refletindo a relação de subordinação entre governantes e governados (essa, portanto, caracterizada como relação entre desiguais).

\footnotetext{
${ }^{16}$ BOBBIO, Norberto. Estado, Governo e Sociedade - Para uma teoria geral da Política. São Paulo (SP), Paz e Terra, 1997/6a Edição, página 14.
} 
Já a sociedade natural, como descrita pelos jusnaturalistas, ou a sociedade de mercado, na pretensa idealização dos economistas clássicos, seriam caracterizadas por relações entre iguais ou de coordenação. E aqui, cabe ressaltar, trata-se apenas de trazer para o exame da questão modelos idealizados que sirvam ao propósito da distinção, sem qualquer juízo de valor.

Tanto que Bobbio salienta que, com o nascimento da economia política, da qual acaba derivando a diferenciação entre a esfera das relações econômicas e a esfera das relações políticas, entendida as relações econômicas como relações substancialmente de desiguais por efeito da divisão do trabalho, mas formalmente iguais no mercado, a dicotomia público-privado apresenta-se sob a forma de distinção entre sociedade política e sociedade econômica. Ou ainda, entre a sociedade do citoyen, que atende ao interesse público, e a sociedade do bourgeois, que cuida dos próprios interesses privados, seja em concorrência ou em colaboração com outros indivíduos.

"Assim também a distinção jusnaturalista entre estado de natureza e estado civil se recompõe, através do nascimento da economia política, na distinção entre sociedade econômica (e enquanto tal não política) e sociedade política; e posteriormente, entre sociedade civil (entendida hegelianamente, ou melhor, marxianamente, como sistemas das necessidades) e estado político: donde então se deve notar que a linha de separação entre estado da natureza, esfera econômica, sociedade civil, de um lado, e estado civil, esfera política, de outro lado, passa sempre entre sociedade de iguais (ao menos formalmente) e sociedade de desiguais". ${ }^{17}$

Outra distinção conceitualmente relevante para a dicotomia entre público e privado é a relativa à fonte, no sentido técnico-jurídico do termo, respectivamente do direito público e do direito privado, ou seja, a Lei estrito senso e o contrato, "negócio jurídico". O direito público, como sabemos, sendo aquele posto pela autoridade política detentora do poder e habitualmente reforçado pela coação. $\mathrm{O}$ direito privado, ou o "direito dos privados", como registra o Bobbio, como o conjunto de normas que os singulares estabelecem para regular suas recíprocas relações, em especial as patrimoniais, mediante acordos bilaterais.

A superposição das duas dicotomias, privado/público e contrato/Lei, revela, de acordo com Bobbio, toda a sua força explicativa da doutrina moderna do direito natural, pela qual o contrato é a forma típica com que os indivíduos

\footnotetext{
${ }^{17}$ Obra cit., pág 17
} 
singulares regulam suas relações no estado de natureza, ou seja, no estado em que ainda não existe poder público, enquanto a Lei, definida como a expressão mais alta do poder soberano (voluntas superioris), é a forma com a qual são reguladas as relações dos súditos entre si, e entre o Estado e os súditos, na sociedade civil, isto é, "naquela sociedade que é mantida junta por uma autoridade superior". ${ }^{18}$

Para Bobbio, a expressão desta dupla dicotomia é convalidada por Kant, para quem o direito privado ou dos privados é o direito do estado da natureza, cujos principais institutos são a propriedade e o contrato entre as partes, enquanto o direito público é o que emana da Lei, estabelecida pelo Estado, constituído por meio da supressão do estado de natureza e o qual estabelece o direito positivo no sentido próprio da palavra. Este direito positivo tem força vinculatória passível de coerção. Vale dizer, seguindo os passos de Bobbio, que para Hegel, um pensador pós-naturalista, um instituto de direito privado como o contrato não pode ser elevado a fundamento legítimo do Estado. O vínculo contratual é revogável pelas partes, enquanto o vínculo que une Estado e cidadãos é irrevogável. Além disso, assinala Hegel, o Estado pode pretender dos cidadãos até o sacrifício do bem maior, que é a vida (no caso de guerra, por exemplo).

A terceira expressão da dicotomia público/privado, conforme os ensinamentos de Bobbio, revela-se na confrontação entre justiça comutativa e justiça distributiva. Haveria duas formas clássicas de justiça, segundo o pensador italiano. A justiça comutativa é aquela que preside as trocas, e para que uma troca seja justa as coisas trocadas devem ser de igual valor. A justiça distributiva é aquela na qual se inspira a autoridade pública na distribuição de obrigações ou benefícios.

Neste caso, a pretensão do Poder Público é que a cada um seja dado o que lhe cabe com base em critérios que podem mudar segundo a diversidade das situações e dos pontos de vista. Exemplos: "a cada um segundo o seu mérito", "a cada um segundo a sua necessidade", ou "a cada um segundo o seu esforço e trabalho", podendo-se identificar, em cada um desses critérios uma inspiração ou um fundamento de caráter ideológico. Em resumo, a Justiça comutativa é definida como a que tem lugar entre as partes; a distributiva, como a que tem lugar entre o todo e as partes.

\footnotetext{
${ }^{18}$ Obra cit., pág. 18
} 
Além dos significados descritivos, há um aspecto axiológico na grande Dicotomia Público/Privado. Seus dois termos ganham um peso valorativo, no sentido de que, no emprego, são contraditórios, um ente não podendo ser simultaneamente público e privado, e muito menos nem público nem privado. Isso significa, conforme nos alerta Bobbio, que estaremos sempre nos deparando com o primado do privado sobre o público ou com o primado do público sobre o privado, e essas variações dar-se-ão por razões históricas, sociológicas, econômicas e até culturais que estão na base da formação das sociedades.

Hegel alertava para o risco de degeneração do Estado com um novo feudalismo, que ocorreria quando o direito privado tomasse a dianteira do direito público. Adverte Bobbio, no fim do primeiro capítulo de Estado, Governo, Sociedade, que os processos de integração da dicotomia, se assim podemos dizer, ou seja de "publicização" do privado e de privatização do público, não são incompatíveis, e complementam-se um ao outro.

"O Estado pode ser corretamente representado como o lugar onde se desenvolvam e se compõem, para novamente decompor-se e recompor-se, esses conflitos, através do instrumento jurídico de um acordo continuamente renovado, representação moderna da tradicional figura do Contrato Social". ${ }^{19}$

Nesta passagem, sobre a dinâmica dos conflitos entre direito público e privado, parece emergir a crença de Bobbio no permanente aperfeiçoamento do sistema. Em outras palavras, divergindo de uma visão marxista, que preconiza o fim do sistema para a inauguração de uma nova realidade, Bobbio deixa transparecer a sua convicção na evolução do próprio sistema para o melhor, tendo como instrumento o direito democraticamente estabelecido.

O segundo capítulo de Governo, Estado, Sociedade passa a discorrer sobre a sociedade civil, esclarecendo que na linguagem política contemporânea, sociedade civil é expressão geralmente empregada como um dos termos da grande dicotomia sociedade civil/Estado. Negativamente, por sociedade civil entender-seia a esfera das relações sociais não reguladas pelo Estado, enquanto esse seria o conjunto dos aparatos instituídos por um sistema organizado com poder coercitivo. Mas as definições não estão livres de controvérsia.

\footnotetext{
${ }^{19}$ Obra cit., pág. 27
} 
Para o mundo constituído a partir da visão burguesa pós-Revolução Francesa, o Estado tem uma noção restritiva: a afirmação dos direitos naturais que pertencem ao indivíduo e aos grupos sociais independentemente do Estado e que como tais limitam e restringem a esfera do poder político, aliada à descoberta de uma esfera de relações inter-individuais, como são as relações econômicas, para cuja regulação não se faz necessária a existência de um poder coativo, posto que elas se auto-regulariam. Sintetizaria esta percepção, segundo Bobbio, a célebre frase de Thomas Paine ${ }^{20}$ de que "a sociedade é criada por nossas necessidades e o Estado por nossa maldade".

Por este entendimento, todo o homem é naturalmente bom e toda sociedade, para se conservar e prosperar, precisa limitar o emprego das Leis civis impostas com a coação, a fim de permitir a máxima explicitação das leis naturais que não carecem de leis positivas para ser aplicadas. Conforme ensina Bobbio, esta visão extrema propugna a dilatação do direito privado para que os indivíduos venham a regular suas relações recíprocas guiados por seus reais interesses.

O termo sociedade civil nasce da contraposição entre uma esfera política e uma esfera não política. Então seria tudo aquilo que sobra uma vez que já foi delimitado o âmbito no qual se exerce o poder estatal, ou seja, o conjunto de relações não diretamente reguladas pelo Estado. Mas as acepções para o termo são variáveis. Pode-se dizer que a sociedade civil seria a infra-estrutura e o Estado, a superestrutura. Se há várias formas de associações que os indivíduos formam entre si para satisfazer os seus interesses, o Estado se superpõe para regulá-las, mas cumpre também esta função em nome (ao menos em tese) da coletividade, do interesse comum desses indivíduos.

Numa conotação axiologicamente positiva, sociedade civil passa a indicar o lugar onde se manifestam todas as instâncias de modificação das relações de dominação, formam-se os grupos que lutam pela emancipação do poder político, adquirem força os chamados contra-poderes. A esta acepção pode-se também atribuir uma conotação negativa, de germe da degradação social. Numa terceira acepção bastante utilizada, "sociedade civil" tem ao mesmo tempo um significado cronológico e axiológico, representando o ideal de uma sociedade sem Estado, destinada a surgir da dissolução do poder político. Essa visão está presente no

\footnotetext{
${ }^{20}$ Obra cit., página 34
} 
pensamento de Gramsci, conforme ressalta Bobbio, sobretudo nas passagens em que o ideal característico de todo o pensamento marxista sobre extinção do Estado é descrito como "reabsorção da sociedade política pela sociedade civil". ${ }^{21}$ Nessas três acepções elencadas pelo pensador italiano o não-estatal assume três diversas figuras, a saber, a de pré-condição de Estado, ou seja daquilo que ainda não é estatal; a da antítese do Estado, ou melhor, daquilo que se coloca como alternativa ao Estado; e, por fim, a da dissolução e do fim do Estado.

Sociedade civil seria aquilo que circunscreveria o âmbito do Estado. Podese dizer que é o lugar onde surgem e se desenvolvem os conflitos econômicos, sociais, ideológicos, religiosos que as instituições estatais têm o dever de resolver, seja por mediação ou repressão. Neste sentido, os partidos teriam um pé na sociedade civil e um pé nas instituições governamentais, pertencentes ao Estado. Nas recentes teorias sistêmicas, a sociedade civil ocupa o espaço reservado à formação das demandas (input) que se dirigem ao sistema político e às quais o sistema político tem o dever de responder (output). O confronto entre sociedade civil e Estado dá-se então pelo contraste entre quantidade e qualidade das demandas e capacidade das instituições governamentais de dar respostas adequadas e tempestivas.

Cabe lembrar que a sociedade civil representa o lugar onde se formam, especialmente nos períodos de crise institucional, os poderes de fato que tendem a obter uma legitimação própria. Daí, explica Bobbio, emerge "a frequente afirmação de que a solução de uma grave crise que ameaça a sobrevivência de um sistema político deve ser procurada, antes de tudo, na sociedade civil, na qual podem ser encontradas as novas fontes de legitimação e, portanto, novas áreas de consenso". ${ }^{22}$ Conforme fica claro, na esfera da sociedade civil inclui-se também o fenômeno da opinião pública.

O Estado totalitário é aquele em que a sociedade civil perdeu a sua expressão e foi inteiramente absorvida pelo organismo estatal. Não tem, portanto, opinião pública, que é o que lhe garante formalmente distanciamento crítico do Estado.

Bobbio ressalta que o uso atual da expressão "sociedade civil" como um termo indissoluvelmente ligado a Estado, ou ao sistema político, é de derivação

\footnotetext{
${ }^{21}$ Obra cit., pág. 35

${ }^{22}$ Obra cit. , pág. 37
} 
marxiana. A partir dessa visão, a anatomia da sociedade civil deve ser buscada na economia política, o que significa que, para Marx, a sociedade civil é o lugar das relações econômicas, ou, mais precisamente, o lugar onde se constituem "a base real sobre a qual se eleva uma superestrutura política e jurídica". ${ }^{23} \mathrm{O}$ que significa dizer que as instituições políticas e jurídicas têm suas raízes nas relações materiais de existência. Por relações materiais, Bobbio alude a uma das teses fundamentais do "Marx economista", qual seja, a do primado do poder econômico sobre o poder político e a previsão de que por meio do mercado tudo pode se tornar mercadoria, com risco de se fomentar uma sociedade de "mercadorização universal", como ele bem salienta em uma passagem do ensaio "Convite para que se releia Marx", texto de encerramento de Nem com Marx, nem para Marx. ${ }^{24}$

O jusnaturalismo coloca a sociedade fora do Estado, é tudo o que não é o Estado. Mas, como alerta Bobbio, a sociedade civil de Marx - ou melhor, a sociedade por ele examinada e diagnosticada - é a sociedade burguesa - $a$ bürgerlische Gesellschaft -, que, paradoxalmente, tem em comum com a sociedade da tradição jusnaturalista o homem egoísta como sujeito. Para Marx, o Estado não é o "reino da razão", mas o da força. Não é a saída do Estado de natureza, mas a sua continuidade. ${ }^{25}$ A saída do Estado de natureza só seria possível com o fim do Estado, com a sua extinção, pois o Estado, na visão marxiana, é sempre uma ditadura.

Enquanto para Marx o momento da sociedade civil coincide com a base material, para Gramsci o momento da sociedade civil é superestrutural. Trata-se da esfera na qual agem os aparatos ideológicos que buscam exercer a hegemonia e, através da hegemonia, obter o consenso. Bobbio esclarece que, no pensamento jusnaturalista, para o qual a legitimidade do poder político depende de estar ele fundado sobre o contato social, a sociedade do consenso por excelência é o Estado, enquanto no pensamento gramsciano a sociedade do consenso é apenas aquela destinada a surgir da extinção do Estado.

Já a interpretação hegeliana da sociedade civil como o lugar cuja anatomia deve ser buscada na economia política é parcial. A sociedade civil de Hegel representa o primeiro momento de formação do Estado - o Estado jurídico-

\footnotetext{
${ }^{23}$ Obra cit., pág. 38

${ }^{24}$ BOBBIO, Norberto. Nem com Marx, nem contra Marx. São Paulo-SP, Editora UNESP, 2004, pág. 305

${ }_{25}$ Obra cit., pág. 34.
} 
administrativo, cuja tarefa é regular relações externas. A essência do Estado não se exaure, portanto, na sociedade civil. O que caracteriza o Estado com respeito à sociedade civil são as relações que apenas o Estado, e não a sociedade civil, estabelece com os outros Estados. Afirma Bobbio que o Estado propriamente dito representa o momento ético-político, cuja tarefa é realizar a adesão íntima do cidadão à totalidade de que parte, tanto que poderia ser chamado de Estado interno ou interior.

Explica ainda o professor de Turim que o Estado civil hegeliano é, assim, uma forma inferior de Estado, correspondendo ao significado tradicional de societas civilis, e no qual civilis (ou civitas) figura como sinônimo de pólis. O emprego da palavra pólis como origem e precedente histórico de Estado remonta a Aristóteles em A Política. No modelo aristotélico, o Estado é o prosseguimento natural da sociedade familiar, da sociedade doméstica. É sempre portanto uma sociedade natural, que corresponde perfeitamente à natureza social do homem (politikon zoon). O termo societas civilis também vai ser empregado por Hobbes, mas com sentido diverso, que seria a antítese do Estado de natureza, ou seja, uma sociedade instituída artificialmente mediante acordos de indivíduos que abrem mão de direitos em nome da segurança. Assim, se em Hegel o Estado é um desdobramento da natureza, um fato natural, em Hobbes ele surge justamente como anteparo aos conflitos naturais.

Ao longo da modernidade, acabou por prevalecer, no uso da expressão "sociedade civil", o significado de "sociedade artificial", e também de sociedade política e Estado. No debate atual, a contraposição entre sociedade civil e Estado permanece. Explica Bobbio:

"A ideia de que a sociedade civil é o anteato do Estado entrou de tal maneira na prática cotidiana que é preciso fazer um grande esforço para se convencer de que, durante séculos, a mesma expressão foi usada para descrever aquele conjunto de instituições e de normas que hoje constituem exatamente o que se chama de Estado, e que ninguém poderia mais chamar de sociedade civil sem correr o risco de um completo mal-entendido. " 26

Prossegue dizendo que poderia ser correto que o Estado continuasse a ser definido como uma forma de sociedade enquanto durou a controvérsia entre Poder Político e Igreja (em especial até a Idade Média) sobre a delimitação dos seus

\footnotetext{
${ }^{26}$ Obra cit.,pág 49
} 
respectivos limites - uma controvérsia que foi representada, em grande parte da história, como um conflito entre duas sociedades. Bobbio salienta, contudo, que a partir de Maquiavel o Estado não pode mais de forma alguma ser assemelhado a uma forma de sociedade. Quando Maquiavel fala de Estado, pretende falar do máximo poder que se exerce sobre os habitantes de um determinando território e do aparato de que alguns indivíduos do grupo se valem para adquiri-lo e conserválo. Um Estado-máquina, segundo Bobbio, e não um Estado-sociedade.

Após o autor de $O$ Príncipe, portanto, passa a ser incoerente empregar o termo societas civilis para designar ou definir Estado. Nas palavras de Bobbio, seria "incrongruente e desviante". O autor de Estado, Governo, Sociedade esclarece que, a partir do Século XIX, mas marcadamente no Século XX, do processo de emancipação da sociedade do Estado seguiu-se um processo inverso de reapropriação da sociedade por parte do Estado, que transformado em Estado de Direito ensejou por sua vez o Estado social. E este, por ser social, por vezes mal se distingue da sociedade subjacente que ele acaba invadindo por inteiro através da intervenção e da regulação das relações econômicas. Houve também um processo inverso, e a expressão Estado social, hoje, pode ser entendida não apenas no sentido do Estado que permeou a sociedade como também no sentido de Estado permeado pela sociedade, pela maior participação de indivíduos e organizações nas ações, políticas e decisões que emanam da esfera governamental.

Aparentemente, esses dois processos, contraditórios, poderiam conduzir, depois de um certo tempo, de um lado a um Estado totalitário, em que a sociedade estaria eliminada, e de outro, no extremo oposto, a novamente uma sociedade sem Estado. Contudo, esses dois processos estariam muito distantes de uma conclusão - e provavelmente jamais tenham um desfecho -, conforme ensina Bobbio, que sintetiza ao final do segundo capítulo Estado, Governo, Sociedade:

"Sociedade e Estado atuam como dois momentos necessários, separados, mas contíguos, distintos mas interdependentes, do sistema social em sua complexidade em sua articulação interna". ${ }^{27}$

Bobbio segue, a partir daí, para um exame específico da relação entre poder, governo e Estado, não necessariamente nesta ordem. Reafirma que as duas

\footnotetext{
${ }^{27}$ Obra cit.,pág.. 52
} 
fontes principais e irrecorríveis para o estudo do Estado são as histórias das instituições políticas e a história das doutrinas políticas. A história das instituições pode ser extraída da história das doutrinas, mas ambas não devem ser confundidas. Numa perspectiva histórica, indica que Hobbes foi identificado com o Estado absoluto, Locke com a monarquia parlamentar, Montesquieu com o Estado limitado, Rousseau com a democracia, Hegel com a monarquia constitucional e assim por diante,

Esclarece que a primeira fonte para o estudo das doutrinas é fornecida pelos historiadores. Por exemplo, para estruturar sua teoria de Poder, Maquiavel reconstrói a história e o ordenamento das instituições da república romana comentando Lívio. Ao estudo da história, adverte Bobbio, deve seguir o estudo das Leis que regulam as relações entre governantes e governados, o conjunto das normas que constituem o direito público. Porém, mais do que em seu desenvolvimento histórico, o Estado deve ser estudado em si mesmo, em suas estruturas, funções, elementos constitutivos, mecanismos, órgãos etc, "como um sistema complexo considerado em si mesmo e nas relações com os demais sistemas". Hoje, o campo de observação está dividido, segundo ele, entre duas disciplinas distintas: a Filosofia Política e a Ciência Política.

Didaticamente, Bobbio atribui à Filosofia Política três tipos de investigação: a) da melhor forma de governo; b) do fundamento do Estado; c) da essência da categoria de político, considerando o aspecto ético. Essas três vertentes de investigação podem ser exemplificadas, segundo Bobbio, por três obras marcantes do pensamento político da modernidade: a Utopia, de Thomas More (1516), que desenha a República ideal; o Leviatã (1651), de Hobbes, que pretende dar uma justificação racional e universal para o Estado e a razão para que os comandos sejam obedecidos; e O Príncipe (1513), de Maquiavel, em que é demonstrado no que consiste a propriedade da atividade política e o que a distingue da moral.

Por sua vez, no que tange a Ciência Política, a investigação nos dias de hoje considera um campo capaz de satisfazer três condições: a) o princípio da verificação ou da falsificação como critério da aceitabilidade dos seus resultados; b) o uso de técnicas de razão que permitam dar uma explicação causal em sentido forte ou mesmo em sentido fraco do fenômeno investigado; c) a abstenção ou 
abstinência (o mais difícil a ser feito, algo que raramente os analistas políticos conseguem) dos juízos de valor - ou "avaloratividade".

Mas, além dos dois campos convencionalmente denominados, da Filosofia e da Ciência Política, o tema Estado pode ser abordado de diferentes pontos de vista, como o sociológico e o estritamente jurídico, como preconiza Weber. Aqui Bobbio alerta que é importante fazer uma distinção: a doutrina social do Estado, da qual se ocupa a sociologia, tem por conteúdo a existência objetiva, histórica ou natural do Estado, enquanto a doutrina jurídica se ocupa das "normas jurídicas que naquela existência real devem se manifestar". Já para Kelsen, conforme referido de início, o Estado será resolvido totalmente no Ordenamento Jurídico, dispensando uma análise sociológica.

Neste sentido, o direito é visto como o regulador da atividade do Estado dedicada à produção de normas. Contudo, esta percepção teria sido de certa forma suplantada pelo Estado social. Como já percebemos, a sociologia jurídica tem como objeto o Estado como forma complexa de organização social, do qual o direito é apenas um dos muitos elementos constitutivos. ${ }^{28}$ Grosso modo, desde o século passado, as teorias sociológicas do Estado dividem-se, conforme os ensinamentos de Bobbio, em uma visão funcionalista, dominante na Political Scince americana e com forte influência na Europa ocidental, e uma visão marxista. Essa segunda distingue em cada sociedade dois momentos históricos, que seriam a base econômica e a superestrutura, sendo que as instituições políticas, ou seja, o Estado propriamente dito, pertenceriam à Superestrutura, cujo o momento subjacente, as relações econômicas, estariam determinados pela forma de produção, se capitalista ou centralizada.

$\mathrm{Na}$ concepção funcionalista, não existem diversidades de planos, e a função política, exercida pelo conjunto das instituições do Estado, é uma das funções fundamentais do próprio sistema social. Aqui o subsistema preeminente não é o econômico, como na abordagem marxiana, mas o cultural, pois a máxima força coesiva de todo o grupo social dependeria da adesão aos valores e às normas pré-estabelecidas, o que deixa claro o caráter hobbesiano da Teoria Funcionalista. A teoria marxiana, enfatiza Bobbio, é dominada pelo tema da ruptura da ordem

\footnotetext{
${ }^{28}$ Obra cit.,pág. 57
} 
estabelecida, onde a passagem de uma ordem à outra dá-se através da exploração das contradições inerentes ao sistema. Afirma Bobbio:

"Pode-se acrescentar que a concepção funcionalista é sob certos aspectos análoga àquela contra qual Marx travou uma de suas batalhas teóricas mais célebres, a concepção da economia clássica segundo a qual a sociedade civil, não obstante os conflitos que a agitam, obedece a uma espécie de ordem preestabelecida e goza da vantagem de um mecanismo o mercado - destinado a manter o equilíbrio através de um contínuo ajustamento dos interesses concorrentes". ${ }^{29}$

Portanto, resume o pensador de Turim, enquanto a primeira (a teoria funcionalista) ocupa-se do problema da coesão e da conservação, a segunda (visão marxiana) preocupa-se estritamente com o problema da mudança social. Os marxistas - e é Bobbio quem o diz, de forma taxativa - preconizam "a grande mudança", aquela que coloca o sistema em crise para estabelecer uma nova ordem.

Porém, na segunda metade do século $\mathrm{XX}$, o ponto de vista que passou a prevalecer no enfrentamento desta questão teórica da sociedade foi o sistêmico, decorrente da teoria dos sistemas, cujos principais representantes, lembra Bobbio, são David Eaton e Gabriel Amond. Assim, a função das instituições políticas é a de dar respostas às demandas provenientes do ambiente social ou, segundo uma terminologia corrente, de converter as demandas em respostas. Esta representação sistêmica, assinala Bobbio, é compatível com ambas as teorias gerais da sociedade, na medida em que propõe um esquema conceitual para analisar como as instituições políticas funcionam, como exercem a função que lhes cabe, seja qual for a interpretação que delas se faça.

Com a emancipação da sociedade industrial inverteu-se a relação entre instituições políticas e sociedade. Hoje, a sociologia política é uma das ciências sociais. O Estado, como sistema político, aparece, em relação ao sistema social, como um subsistema. Mas quando exatamente nasceu o Estado? A tese recorrente que percorre toda a história do pensamento político afirma que o Estado, entendido como ordenamento político de uma determinada comunidade, nasce da dissolução da comunidade primitiva formada pelos laços de parentesco e da formação de comunidades mais amplas derivadas da união de vários grupos familiares, geralmente por razões de sobrevivência.

\footnotetext{
${ }^{29}$ Obra cit.,pág.. 59
} 
Se para os pensadores contemporâneos o Estado nasce com o início da Era Moderna (o advento do Contrato Social), a concepção mais antiga, referida acima, indica o seu nascimento pela passagem da idade primitiva, selvagem e bárbara, à idade civil - entendendo-se como civil o cidadão civilizado. Teoricamente, portanto, é possível haver sociedades sem Estado, ao menos do ponto de vista antropológico. Seriam aquelas desprovidas de uma organização política.

Independentemente da existência do Estado, formas de poder - e, portanto, de poder político - estão presentes ao longo da trajetória da humanidade. De Aristóteles vem a tipologia clássica, que distingue três tipos: o poder do pai sobre os filhos, do senhor sobre os escravos, do governante sobre os governados. A partir de Hobbes, o poder político assume uma conotação que permanece estável até os nossos dias, e tem no uso exclusivo da força por parte do Estado como a sua principal característica. $\mathrm{Na}$ verdade, devemos dizer que a força empregada sobre determinado território de forma soberana é a expressão própria do Estado moderno até os dias de hoje. Nas suas lições, Bobbio lembra das três formas de poder que marcaram a constituição do Estado na história e que seriam o econômico, o ideológico e o político. O Estado moderno ocidental é o do primado do poder político.

Consoante a Filosofia Política clássica, salienta Bobbio que um poder fundado apenas na força não tem legitimidade. O que significa que as forças políticas sempre buscarão em maior ou menor grau uma base moral para o exercício do poder. Contudo, com o advento do positivismo jurídico, Bobbio ressalta que o tema da legitimidade foi completamente subvertido. Enquanto em todas as teorias precedentes o poder deve estar sustentado por uma justificação ética para ser perene, e portanto a legitimidade é necessária para a sua efetividade, com as teorias positivistas "abre-se o caminho para a tese de que apenas o poder efetivo é legítimo". ${ }^{30}$ Lembre-se que, para Kelsen, uma autoridade de fato constituída é o governo legítimo, o ordenamento coercitivo imposto por esse governo é um ordenamento jurídico, e a comunidade constituída por tal ordenamento é um estado no sentido do direito internacional .

Mas Bobbio adverte, em contraponto, que um ordenamento jurídico legítimo na medida em que eficaz e como tal reconhecido pelo ordenamento

\footnotetext{
${ }^{30}$ Obra cit., pág.92
} 
internacional pode e deve ser submetido a juízos axiológicos, juízos esses que sejam capazes até de pôr fim à eficácia de um ordenamento moralmente ilegítimo. Percebemos aqui que Bobbio procura compatibilizar a legitimidade da regra efetiva do ordenamento positivo não apenas com critérios axiológicos das quais poderia derivar a legitimidade.

Recorre a Weber, neste sentido, para lembrar que há três tipos puros de poder, que seriam o tradicional, que tem base na natureza ou na religião e cuja característica marcante é a sacralidade; o racional/legal, que advém de uma Constituição, caracterizado pelo comportamento em conformidade com a Lei; e o carismático, que tem como traço o populismo e que dependerá, sempre, dos dotes do chefe. Esses foram ao longo da história os fundamentos reais do poder, não os formais, presumidos ou declarados.

Para sintetizar o que foi dito até aqui, podemos dizer que o Estado é um ordenamento (jurídico) por excelência destinado a exercer o poder soberano sobre um dado território, no qual estão subordinados os sujeitos a eles pertencentes, tomando o cuidado, como ensina Bobbio, de não ceder ao reducionismo de Kelsen. Como não existe Estado sem poder governante, deve-se perguntar, como Platão ${ }^{31}$ o fez, o que seria melhor, o governo das Leis ou o governo dos homens? Ora, responde o próprio Platão, "onde a Lei é súdita dos governantes e privada de autoridade, vejo pronta a ruína da cidade (do Estado); e onde, ao contrário, a Lei é senhora dos governantes e os governantes seus escravos, vejo a salvação da cidade e a acumulação nela de todos os bens que os Deuses costumam dar às cidades".

Aristóteles retoma o problema, como lembra Bobbio, quando inicia o discurso sobre as diversas constituições monárquicas: "é mais conveniente ser governando pelo melhor dos homens ou pelas melhores leis?" , indaga de forma retórica. Bobbio realça a resposta do filósofo de Estagira: "A Lei não tem paixões, que ao contrário se encontram necessariamente em toda a alma humana". A questão é que, no início de todo bom ordenamento, além do fundamento na tradição, nas Leis naturais, deve existir um homem sábio, "um legislador extraordinário", como se referiu Rousseau. E aqui nos deparamos mais uma vez com a questão da legitimidade.

${ }^{31}$ PLATÃO. Diálogos III - A República. Rio de Janeiro-RJ, Ediouro/Coleção Universidade, 1985. 
Afirma Bobbio, recorrendo a Bodin:

"O problema das Leis fundamentais e da sua força vinculatória é um tema que aparece em todos os tratados dos juristas que se preocupam em fixar, com normas claras e precisas, os limites do poder do rei: são as normas daquela constituição não escrita que regula as relações entre governantes e governados. O rei (ou governante) que viola as leis naturais e divinas torna-se um tirano; o rei que viola as normas fundamentais é um usurpador". ${ }^{32}$

No quarto e último capítulo de Estado, Governo, Sociedade, intitulado Democracia e Ditadura, Bobbio trata das teorias das formas de governo, de Platão e Aristóteles a Políbio. Discorre sobre as democracias formais e as democracias substanciais, e faz um detido exame sobre as diferentes formas de ditadura, desde os antigos até os nossos dias, mostrando a distinção entre ditadura e tirania, entre ditadura soberana ou comissária e a ditadura dos tempos modernos. A matéria é detalhada em A Teoria das Formas de Governo.

\footnotetext{
${ }^{32}$ Obra cit.,pág.. 96
} 


\section{3}

\section{O Exame das formas de governo}

Em A Teoria das Formas de Governo, Bobbio faz um mergulho profundo nas formas de estruturação de governo em suas diferentes variantes, recorrendo às conceituações clássicas elaboradas primeiramente por Platão e Aristóteles, depois por Políbio e Maquiavel, passando por Montesquieu e Hegel até chegar a Marx. Discorre ainda, por extensão, e sempre analiticamente, sobre ditadura e suas diferentes acepções, sobre despotismo e sobre democracia (a formal e a substancial, uma diferenciação cada vez mais relevante no mundo de hoje). A obra constitui assim um notável curso de teoria das formas de governo. Com efeito, é exatamente do que se trata: a compilação de uma série de aulas de Filosofia Política ministradas pelo autor na Faculdade de Ciências Políticas de Turim nos anos de 1975 e 1976.

Dividido em capítulos correspondentes aos pensadores que representam marcos na evolução do pensamento político ocidental, o livro é ao "mesmo tempo uma investigação histórica e conceitual da teoria das formas de governo" na trajetória do pensamento político, como oportunamente esclarece a apresentação de seu editor (UnB), na 10a Edição. ${ }^{33}$. O próprio Bobbio comenta a obra, em nota introdutória:

"Se há uma razão que justifique um curso de filosofia política, distinto dos cursos sobre história das doutrinas políticas e da ciência política, é a necessidade de estudar e analisar os chamados "temas recorrentes", quer dizer, os temas que têm sido propostos e discutidos pela maioria dos escritores políticos (...).".34

Didático na justificativa, Bobbio passa, de imediato, ao exame da temática lançando o seu olhar crítico para Kelsen. Jurista positivista, mas, antes de tudo, filósofo do Direito, Hans Kelsen afirma, na sua investigação para uma Teoria do Estado que: "Democráticas são as formas de governo em que as leis são feitas

\footnotetext{
${ }^{33}$ BOBBIO, Norberto. A Teoria das Formas de Governo. Brasília (DF), Editora Universidade de Brasília, 10a Edição.

${ }^{34}$ Obra cit.,pág.. 31
} 
sobre os quais elas se aplicam. Ou seja, onde o povo faz as leis que o governam". ${ }^{35}$

Partindo desta premissa positivista, no sentido jurídico do termo, Bobbio vai questionar em A Teoria das Formas de Governo (assim como o faz também em Estado, Governo, Sociedade) se um Estado democrático pode sobreviver numa sociedade que não é democrática.

Convém, neste ponto, destacar a distinção entre positivismo jurídico e positivismo no sentido estritamente filosófico do termo. Essa distinção é executada com extremo rigor pelo próprio Bobbio em $O$ Positivismo Jurídico e em Jusnaturalismo e positivismo jurídico. A expressão "positivismo jurídico" deriva da locução direito positivo, que é contraposta ao direito natural. Como o próprio pensador assinala, embora tenha havido no século XIX uma co-relação entre os dois termos, uma vez que alguns positivistas jurídicos eram também positivistas filosóficos, suas origens e sentido são diferentes. O positivismo filosófico, como escola, tem origem na França; o jurídico, na Alemanha. Mas os dois termos já haviam sido empregados na Antiguidade tanto por Platão quanto por Aristóteles. ${ }^{36}$

Toda a tradição do pensamento jurídico ocidental é dominada pela oposição entre direito positivo e direito natural. Em torno desta distinção e como efeito dela dá-se também o exame da Teoria do Estado. Para um jurista positivista, não há direito que o positivo. Para ele, o direito natural simplesmente não é direito. Para o jusnaturalista, toda norma positiva teria, na sua essência, uma fonte na natureza, que a condiciona. Mas o que é a natureza, no sentido jurídico, senão a interpretação que o homem faz dela?, eis o questionamento positivista.

Ora se há um valor moral inspirando uma norma positiva, esse valor moral foi elaborado pelo homem, e desta forma não pode estar na natureza. Ocorre que o homem também é natureza. Essa discussão será retomada com maior profundidade no Capítulo 5 (Positivismo e Jusnaturalismo - a estruturação do Poder). Por ora cumpre saber que, como jurista positivista - embora um positivista não radical, posto que reconhece as influências sociais sobre o Direito , Bobbio questiona se um Estado democrático pode sobreviver numa sociedade que não é democrática.

\footnotetext{
${ }^{35}$ BOBBIO, E.G.S., pág.139.

${ }^{36}$ BOBBIO, Norberto. Positivismo Jurídico. São Paulo (SP), Ícone Editora, 2006, pag. 16.
} 
O questionamento, ao meu ver, perpassa toda a análise e descrição que o autor elabora em seu curso sobre Teoria das Formas de Governo. Portanto, o poder é o que realmente importa, segundo Bobbio, em qualquer diagnóstico político. Mais precisamente, a maneira como este poder se estrutura e se justifica, ou seja, a sua gênese, é o ponto de partida relevante a se considerar no exame das formas de governo. É isso é que vai determinar, em última instância, o caráter de um regime, muito mais do que qualquer aspecto formal, por mais relevante que esse possa vir a ser. Para um pensador que está alinhado com o positivismo jurídico - ou um normativista -, este ponto de vista tem ainda maior relevância.

Se para Marx o despotismo se encarna no Estado, para Bobbio essa visão é insuficiente para a elaboração de uma precisa doutrina acerca do Estado (uma doutrina socialista, que seja), posto que se preocupa mais com a tradição histórica do que com a organização do poder político - ou de que forma o poder político se organiza. Portanto, o problema da democracia no mundo moderno não é apenas em quem se vota, mas onde se vota e se delibera coletivamente, visando o controle democrático do poder econômico. Bobbio não ignora as dificuldades da democracia, mas prefere insistir em seus méritos, e o freio ao poder econômico revela a sua preocupação social, ou seja, atinente a uma democracia distributiva.

O estudo das formas de governo - e, por extensão, das formas possíveis de democracia -, com abordagem ao mesmo tempo histórica, descritiva e analítica, como dito acima, nos permite pisar com segurança no terreno da política, distinguido o que está apenas na forma (e na superficialidade) daquilo que se encontra na substância. O pensador político não deve se iludir com as formas de governo. Estabelecido contato com a aparência, deve prospectar o seu conteúdo, identificando a sua origem.

Portanto, a tipologia das formas de governo pode ser empregada de forma axiológica ou meramente sistemática, ensina Bobbio em A Teoria das Formas de Governo. Diante da variedade das formas de governo, existem três posições possíveis: 1. Todas são boas; 2. Todas são más; 3. Algumas são boas e algumas são más. Todas as formas de governo seriam apropriadas à situação histórica concreta que a produziu. Platão assume a segunda posição: a rigor, todas as formas são más, pois representariam a corrupção da única forma boa. A visão aristotélica privilegia a descrição, o que faz com que possamos alinhá-lo na 
terceira posição, ou seja, algumas formas são boas, outras, más. Vejamos essas variações de conceitos mais detalhadamente a partir do estudo da obra em tela.

A rigor, nenhuma teoria pode ter apenas uma função descritiva, como reconhece o próprio Bobbio, embora seja possível fazer, para uma abordagem didática da matéria, uma clara divisão entre os dois aspectos: o descritivo e o prescritivo. Qualquer teoria apontará, em maior ou menor grau, quais seriam as melhores e quais seriam as piores formas de governo. As primeiras grandes classificações das formas de governo, como as de Heródoto, Platão e Aristóteles, são extraídas da observação histórica, considerando os vários tipos de constituição política.

Mas não há tipologia que se esgote exclusivamente na função meramente descritiva. Bobbio alerta em seu curso que uma tipologia pode igualmente ser empregada de modo sistemático e axiológico, o primeiro servindo para ordenar os dados colhidos na investigação, o segundo para definir uma ordem de preferência entre os tipos de classe dispostos sistematicamente. Esta distinção é relevante, haja vista que o pensador - e mais precisamente o cientista social - apresenta, no desenvolvimento de sua atividade, e ainda que de forma subjacente, projetos de revisão da sociedade.

Na definição clássica que é o ponto de partida de todas as outras, e que, conforme Bobbio, remonta a Heródoto em sua História, temos o governo de muitos, o governo de poucos e o governo de um só, o que poderia corresponder, embora as expressões ainda não fossem empregadas então, à democracia, à aristocracia e à monarquia. Contudo, essas três formas teoricamente boas, ou seja, governos de muitos, de poucos e de um só, já em Heródoto encontram correspondentes más - as formas degeneradas. Assim, monarquia, aristocracia e democracia podem transformar-se em, respectivamente, tirania, oligarquia e demagogia.

Para se chegar à classificação sêxtupla, com três formas más que correspondem à deturpação das três formas boas é preciso fazer o cruzamento de dois critérios, o primeiro dos quais reponde à pergunta "quem governa" e o segundo, "como se governa". No esquema aristotélico, de caráter mais descritivo, a monarquia, a aristocracia e a democracia podem ser boas ou más. No esquema de Políbio, observador e historiador da República romana e não apenas das cidades-estado gregas, o modelo se apresenta, resumidamente, da seguinte forma: 
se um (quem?) governa (como?) bem, é uma monarquia; se um governa mal, é uma tirania, a mesma tábua de aferição podendo ser empregada para o governo de poucos (aristocracia versus a sua forma degenerada oligarquia) e para o governo de muitos (democracia x oclocracia).

Em A República, Platão (428-347 a.C) busca descrever a república ideal que tem como objetivo a realização de justiça, o que, adverte Bobbio "significa atribuir a cada um o que lhe cabe de acordo com as suas aptidões". ${ }^{37}$ A visão platônica, porém, é desencorajadora, no sentido de que as três formas clássicas de governo só ocorrem na variante má porque nenhuma delas estaria ajustada ao que ele considera uma constituição política ideal, conforme esclarece Bobbio no segundo capítulo de A Teoria das Formas de Governo.

"Na verdade, Platão - como todos os grandes conservadores, que sempre vêem o passado com benevolência e o futuro com espanto - tem uma acepção pessimista da história (uma concepção "terrorista", como diria Kant). Vê a história não como progresso indefinido, mas, ao contrário, como regresso definido; não como uma passagem do bem para o mal, mas como o regresso do mal para o pior. Tendo vivido na decadência da gloriosa democracia ateniense, examina, analise e denuncia a degradação da polis: não o seu esplendor. É também - como todos os grandes conservadores - um historiador (e um moralista) da decadência das nações, mais do que de sua grandeza. Diante da degradação contínua da história, a solução só pode [na visão platônica, identificada por Bobbio neste trecho] estar fora da história". ${ }^{38}$

Assim, as constituições corrompidas que Platão examina detalhadamente no Livro VIII de A República são, em ordem decrescente, originariamente quatro: timocracia, oligarquia, democracia e tirania. A timocracia (de timé, honra) é uma forma introduzida por Platão em sua classificação para designar a transição entre a constituição ideal e as três formas ruins tradicionais. No seu foco está os vícios e as virtudes dos governantes, e portanto, a teoria platônica concebe a sociedade como um organismo à imagem do homem. A corrupção no Estado ocorre estritamente devido à discórdia entre os indivíduos, a discórdia, sendo, por sua vez, uma decorrência dos vícios. Da discórdia nascem os males da fragmentação das nações. O tema central para Platão é, assim, segundo Bobbio, a "unidade", e não a questão da liberdade do homem frente ao Estado.

\footnotetext{
${ }^{37}$ Obra cit., pág. 45

${ }^{38}$ Obra cit., pág. 46
} 
Admirador de Esparta e seu espírito guerreiro, Platão idealiza a sua república como uma constituição de homens que primam pelas honrarias. O desejo que prevaleceria dos indivíduos integrantes de uma timocracia seria exatamente o de honraria (caráter espartano e guerreiro, portanto), enquanto na oligarquia, o que se sobrepõe é a fome de riquezas; na democracia, um desejo "imoderado" de liberdade (licenciosidade); e, na tirania, a violência como recurso à obtenção e à manutenção do poder.

$\mathrm{Na}$ concepção platônica de república ideal, esmiuçada no exame de Bobbio, três tipos de alma humana deverão se conjugar, a racional, a passional e apetitiva, cada uma em sua atividade especifica correspondente de filósofogovernante, o guerreiro e o homem produtor. A conjugação dessas características poderá gerar a necessária unidade de que a República carece para prosperar. São seis as formas estabelecidas por Platão, como decorrência das originais: timocracia (que seria a transição entre as diferentes formas), oligarquia, democracia (vista, neste caso, com desconfiança por Platão, devido à possibilidade de demagogia), tirania, monarquia e aristocracia, sendo as últimas duas, para o filósofo conservador, as ideais.

Esclarece, contudo, Bobbio que, se colocarmos em ordem decrescente as três formas boas e más, a partir do desdobramento da confrontação feita pelo próprio Platão em A República, quais sejam monarquia, aristocracia e democracia, com as variantes tirania, oligarquia e demagogia (ou oclocracia, segundo a terminologia posterior de Políbio), veremos que democracia seria a pior das formas boas (pelos critérios clássicos platônicos) e a melhor das formas más. Bobbio salienta que, em qualquer hipótese, as formas boas são aquelas em que o governo "não se baseia na violência, e sim no consentimento dos cidadãos; onde ele atua de acordo com leis estabelecidas" . ${ }^{39}$ Winston Churchill não foi, portanto, original muito menos pioneiro quando declarou, em meados do século $\mathrm{XX}$, que democracia era a pior forma de governo, com exceção de todas as demais. Ou seja, dentro das circunstâncias possíveis, é a democracia, a despeito de suas falhas, que permite o governo do consentimento. Bobbio estabelece, em acréscimo, uma ordem de aceitabilidade: monarquia, aristocracia, democracia positiva, democracia negativa (demagogia), oligarquia, tirania.

\footnotetext{
${ }^{39}$ Obra cit.,pág.. 54
} 
A distinção entre os conceitos de tirania e ditadura tem importância acadêmica, e é feita com precisão em A Teoria das Formas de Governo, (bem como em Estado, Governo, Sociedade, no Capítulo IV). Ditadura na concepção moderna e, sobretudo, contemporânea é aquele regime em que o governo domina as três esferas de poder (Executivo, Legislativo e Judiciário). Bobbio explica que à medida em que a democracia foi sendo considerada como a melhor forma de governo (ou a menos pior, dentro das circunstâncias), mais apropriada do ponto de vista econômico às sociedades mais evoluídas, a teoria das formas de governo simplificou a tipologia tradicional e polarizou-a em torno da dicotomia democracia-autocracia. E explica:

"Hoje está de tal maneira generalizado o costume de chamar de 'ditaduras' todos os governos que não são democratas, e que geralmente surgiram derrubando democracias precedentes, que o termo tecnicamente mais correto 'autocracia' acabou por ser relegado nos manuais de direito público, e a grande dicotomia hoje dominante não é a que se funda sobre a contraposição entre democracia e autocracia, mas a que contrapõe (embora com um uso distorcido do primeiro termo) a ditadura à democracia". ${ }^{40}$

Bobbio esclarece que o termo ditadura aplicado a todos os regimes que não são democráticos difundiu-se sobretudo após a Primeira Guerra mundial, a partir do debate sobre a forma de governo instaurada na União Soviética pelos bolcheviques (a "ditadura do proletariado"), e também para designar regimes fascistas, a começar pelo italiano, com restrito espaço às liberdades individuais e ao anteparo legal do cidadão face ao poder coercitivo penal do Estado.

Adverte Bobbio que tanto quanto tirania, despotismo e autocracia, ditadura é um termo que vem da antiguidade clássica. Mas, ao contrário desses, teve em sua origem e durante séculos, sobretudo durante a República romana, uma conotação positiva. Lembra Bobbio que Roma, do século 500 a.C até o III século de nossa era, deu a designação de dictator ao governante nomeado pelos cônsules para, em circunstâncias extraordinárias (por exemplo, guerras civis), exercer o poder também de forma excepcional, e com tempo pré-determinado.

"A exorbitância do poder do dictator era contrabalançada pela sua temporalidade: o ditador era nomeado apenas para a duração do dever extraordinário que lhe fora confiado. $\mathrm{O}$ ditador era portanto um magistrado extraordinário, mas legítimo, pois sua instituição era prevista pela constituição e o seu poder justificado pelo estado de necessidade". ${ }^{41}$

\footnotetext{
${ }^{40}$ E.G.S., pág. 158

${ }^{41}$ Obra cit.,pág..159
} 
Ressalte-se que, na conceituação tradicional, bem captada tanto por Maquiavel quanto por Rousseau, o ditador exerce funções estritamente executivas, não invadindo o espaço do Legislativo ou do Judiciário, ainda que possa governar fazendo-se valer de determinados gêneros de decretos. Somente na idade moderna, de acordo com Bobbio, o conceito de ditadura foi estendido ao poder instaurador da nova ordem, isto é, um poder que como tal revoga antigas ordens para estabelecer uma nova, por meio da força.

Conhecido como o "jurista do nazi-fascismo" exatamente por advogar o conceito clássico de ditadura inscrito na Constituição de Weimar (a qual ele interpretou em favor do regime que ascendia o poder na Alemanha do pósPrimeira Guerra mundial) Carl Schimitt, em $O$ Guardião da Constituição ${ }^{42}$, distingue a ditadura clássica "comissária" da ditadura dos tempos modernos, revolucionária, que ele denomina de "soberana". A "ditadura comissária" seria aquela que obedece à ordem estabelecida e se efetiva por meio de um dispositivo constitucional previamente definido, enquanto que a soberana vê em todo o ordenamento existente um estado de coisas a ser completamente reformulado, se necessário for, pelo uso da força.

A pior constituição, adverte Aristóteles, a exemplo de Platão, e de acordo com os ensinamentos de Bobbio, é a forma degenerada que deriva da primeira. $\mathrm{O}$ critério de Aristóteles é o interesse comum, e não o uso da força. A questão do público versus o privado, que domina o debate jurídico acerca do Estado, como vimos de início, já estava presente em Aristóteles. É o interesse público que vai definir se uma constituição é boa ou ruim. Aristóteles analisa cada uma das seis formas mencionadas acima (as três teoricamente boas com as suas consequentes degenerações) em especificações históricas, subdividindo-os em muitas espécies particulares, cuja determinação, segundo Bobbio, faz com que o esquema geral pareça muito menos rígido do que ficou consignado na tradição do pensamento político. Por exemplo, explica que a democracia não se resume a um só gênero, mas, ao contrário, a muitos gêneros.

\footnotetext{
${ }^{42}$ SHMITT, Carl. O Guardião da Constituição, Belo Horizonte, Del Rey, 2007.
} 
Aristóteles é realista em sua análise, reproduzida por Bobbio. Afirma o autor de $A$ Política ${ }^{43}$ :

"Na democracia governam os homens livres e os pobres, que constituem a maioria; na oligarquia, governam os ricos e os nobres, que representam a minoria". ${ }^{44}$

A politia de Aristóteles seria, conforme os ensinamentos de Bobbio, um regime que faria a fusão das duas formas, remediando a luta dos pobres contra os proprietários, promovendo a paz social. Aristóteles propõe então, nessa fusão, a conciliação de procedimentos, a busca do meio-termo, a integração das melhores características existentes nos dois sistemas. Afirma também Aristóteles, de acordo com Bobbio, que a melhor comunidade política é aquela que se baseia na classe média.

"Está claro que a forma intermediária é a melhor, já que é a mais distante do perigo das revoluções; onde a classe média é numerosa raramente ocorrem conspirações e revoltas". ${ }^{45}$

A Politia de Aristóteles, portanto, traduz a ideia de que um bom governo seria fruto de uma mistura de diversas formas ("produto de uma mistura", segundo o pensador italiano), o que é relevante porque ainda hoje trata-se de um dos grandes temas do pensamento político ocidental. Aristóteles anteviu também a importância da separação dos poderes, ao propugnar em sua Politia que os poderes de uma nação se controlem reciprocamente. Explica Bobbio que a presença simultânea dos três poderes e seu controle recíproco preserva as constituições mistas da degeneração a que estão sujeitos os governos simples.

Bobbio prossegue seu mergulho na história das formas de governo. Acrescenta que Políbio, que viveu dois séculos antes de nossa era, em Roma, vai afirmar que se deve considerar a constituição de um povo como a causa primordial do êxito ou do insucesso de todas as ações. É ele que, em sua classificação sobre as formas de governo, cria o termo oclocracia (de oclos, que significa multidão) para designar governo das massas, como a forma populista e degenerada de democracia. Há um fatalismo em Políbio, segundo a análise de Bobbio, posto que o seu sistema de classificação de governos vai sempre em

\footnotetext{
${ }^{43}$ ARISTÓTLES. A Política. Rio de Janeiro (RJ), Ediouro/Coleção Universidade, 1985.

${ }^{44}$ A.T.F.G, pág. 60

${ }^{45}$ Obra cit.,pág.. 62
} 
direção ao pior, sendo irrevogável e imutável, no sentido de que uma determinada forma só pode ser substituída por outra específica.

Dizia Políbio, de acordo com os ensinamentos de Bobbio, que há um mal natural em cada forma de governo, como há um mal no ferro (ferrugem) e na madeira (traça). Políbio descreve um círculo perpétuo das formas de governo, após observar o comportamento das cidades-gregas ao longo da história. De acordo com este círculo (ou ciclos sucessivos), do reino passa-se à tirania, da tirania à aristocracia, da aristocracia à oligarquia, da oligarquia à democracia, da democracia à oclocracia, desta novamente ao reino, e sempre nesta ordem e de forma sucessiva. Daí também parte para afirmar que as formas simples de constituição são más, porque engendram este ciclo vicioso, e que o ideal é estabelecer governos que reúnam o que há de melhor dos três tipos básicos de constituição (monarquia, aristocracia e democracia). Somente as formas mistas, como a adotada por Licurgo em Esparta, seriam capazes de gerar estabilidade e prosperidade. Assim como Aristóteles, prescreve a divisão de Poderes que seria sedimentada na Idade Moderna com Montesquieu, ao preconizar que a legitimidade da monarquia está associada à figura do rei; à da aristocracia, à do Senado; à do Parlamento à do povo, engendrando assim uma forma composta de governo, conforme aponta Bobbio.

Na visão do pensador de Turim, a presença simultânea dos três Poderes e seu controle recíproco já eram entendidos no pensamento clássico como uma forma de preservar as constituições das degenerações, uma vez que impediriam os excessos que desencadeiam a violência e provocam mudanças. Maquiavel ${ }^{46}$, com seu realismo, de certa forma rompe com a ideia de ciclos que se repetem de forma infinita. E simplifica a classificação, conforme nos lembra Bobbio. Para o pensador florentino, todos os Estados que existem ou são Repúblicas ou Monarquias, uma vez que as nações ou são governadas por uma pessoa ou por muitas - e é aí que estaria, segundo a concepção maquiavélica, a verdadeira distinção. A conquista e a manutenção do poder só pode se dar de quatro maneiras: pela virtude, pela fortuna (sorte), pela violência ou pelo consentimento dos cidadãos. Principados conquistados pela virtù (pela capacidade do príncipe/governante) tendem a ser mais duradouros. O consentimento do povo,

\footnotetext{
${ }^{46}$ MAQUIAVEL, Nicolau. O Príncipe, Rio de Janeiro-RJ, Bibliex, 1998
} 
por sua vez, também só pode decorrer do reconhecimento da virtude do governante.

Bobbio chega ao fim de A Teoria das Formas de Governo dedicando um capítulo a Marx, antes de discorrer sobre a Ditadura, no capítulo derradeiro (cujos conceitos foram comentados acima). E afirma, de saída:

"Em nenhum lugar de sua imensa obra encontramos qualquer manifestação do interesse de Marx pelo problema da tipologia das formas de governo - que, no entanto, esteve sempre presente nos escritos políticos, de Platão a Hegel". ${ }^{47}$

Ressalta, didaticamente, que o autor de $O$ Capital, ao contrário de Engels (que escreveu A Origem da família, da Propriedade e do Estado), não produziu nenhuma obra dedicada expressamente ao problema do Estado e que sua teoria política "precisa ser extraída de trechos, em geral curtos", de obras de economia, história, políticas, letras etc.

"Penso que uma razão intrínseca do pouco interesse de Marx pela tipologia das formas de governo é a sua concepção caracteristicamente negativa de Estado". ${ }^{48}$

Em Marx, segundo Bobbio, esta concepção negativa de Estado é ainda mais evidente quando se compara com a concepção extremamente positiva feita por seu predecessor e antagonista, Hegel. Para a maior parte dos filósofos clássicos, Hegel incluso, o Estado representa um momento positivo na formação do homem civil. O objetivo do Estado é ora a justiça (Platão), ora o bem comum (Aristóteles), ora a felicidade dos súditos (Leibniz), ora a liberdade (Kant), ora a máxima expressão do ethos de um povo (Hegel), afirma Bobbio.

Marx, ao contrário, sustenta o autor de A Teoria das Formas de Governo, considera o Estado como um "puro e simples instrumento" de poder e de domínio. Portanto, na concepção marxista, o Estado teria duas características principais, de acordo com os ensinamentos de Bobbio: 1) Estado como pura e simples superestrutura que reflete o estágio das relações sociais determinadas pela base econômica; 2) identificado como aparelho de que se serve a classe dominante para manter o seu domínio, motivo pelo qual o objetivo do Estado não seria, como supõem os clássicos, um objetivo nobre, mas o interesse particular de um

\footnotetext{
${ }^{47}$ Obra cit.,pág. 164

${ }^{48}$ Obra cit.,pág. 163
} 
segmento da sociedade. Sendo assim, para Marx, o Estado é sempre uma instituição corrompida. Bobbio lembra uma passagem de A Sagrada Família (1845) em que o pensador alemão afirma que somente a superstição política pode imaginar ainda hoje que a vida civil deve existir dentro do Estado; e que na verdade é o Estado que existe dentro da vida civil. Convergindo, nesse aspecto, com Engels, para quem o Estado é sempre o Estado da classe mais poderosa.

Daí a estruturação do termo "Ditadura do proletariado", que, segundo Bobbio, foi empregada pela primeira vez por Marx em carta escrita a Joseph Weydemeyer, em março de 1852 , e na qual o pensador demonstra que: 1. a existência de classes só está ligada a determinada fase do desenvolvimento histórico da produção; 2. a luta de classes leva necessariamente à ditadura do proletariado; 3. essa ditadura constitui apenas uma passagem para a fase de supressão de todas as classes, a uma sociedade sem classes. ${ }^{49}$ Lênin teria considerado, segundo Bobbio, a carta a Weydemeyer como um dos mais importes documentos do pensamento marxista, e assinalaria que só seria marxista quem estendesse o reconhecimento da luta de classes até a admissão da "ditadura do proletariado", sendo esta a diferença mais profunda entre o marxista e o pequeno burguês. O comunismo emergiria após a ditadura do proletariado e caracterizarse-ia pela ausência de um poder coator e opressivo (Estado).

Rousseau $^{50}$ elucubrou uma democracia direta, ao criticar, em Do Contrato Social, o modelo inglês. Assinala Bobbio que Marx não preconizou a democracia direta propriamente dita, ou seja, a forma de governo pela qual todos participam pessoalmente da deliberação coletiva, mas a democracia eletiva com a revogação do mandato dos eleitos - uma forma de democracia em que os representantes têm seu mandato limitado às instruções recebidas dos eleitores.

"Não há dúvida de que para Marx, ao contrário de todos os escritores políticos que o precederam, a melhor forma de governo é aquela que agiliza o processo de extinção do Estado - e que permite a transformação da sociedade estatal em sociedade não-estatal. A essa melhor forma de governo corresponde a fase que Marx chama de transição (de Estado para a ausência de Estado) e que é, do ponto de vista do domínio de classe, o período da 'ditadura do proletariado'". ${ }^{51}$

\footnotetext{
${ }^{49}$ A.T.F.G, pág. 169

${ }^{50}$ ROUSSEAU, Jean Jacques. Do Contrato Social. São Paulo-SP, Editora Abril/Coleção Os Pensadores, 1983.

${ }^{51}$ A.T.F.G, pág. 172
} 
Dessa incursão retrospectiva à história da Filosofia Política, feito pelas lentes de Bobbio, emerge os principais pontos e uma síntese de seu pensamento. Ao dissecar conceitos, Bobbio cumpre uma das principais funções da Filosofia Política, senão a principal, que é a de construir e reconstruir os raciocínios que giram em torno das questões relativas ao poder. A crença na liberdade e, por consequência, a sua identificação com Kant, são perceptíveis em suas análises.

A aposta na democracia como modelo capaz de pavimentar o caminho para um mundo melhor também resta evidente, mesmo quando o autor de Turim faz uma abordagem descritiva e não analítica dos principais conceitos políticos. Válido é dizer que Bobbio, sem ser um anticomunista, foi um crítico do comunismo. Na verdade, foi um leitor e admirador de Marx e de Gramsci. No entanto, nas palavras de Tosi, "não se deixou seduzir pelo fascínio que o marxismo exerceu sobre uma grande parcela da intelectualidade europeia no segundo pós-guerra" ${ }^{52}$. Manteve, ainda assim, um longo diálogo com os marxistas desde os anos 1950 até a queda do comunismo soviético no início dos anos 1990, e principalmente na década de 1970 , período em que a Itália vivia uma forte polarização.

Bobbio foi desde a luta clandestina contra o fascismo na juventude um liberal. Mas um liberal na acepção política do termo muito mais do que na econômica. Autodenomiava-se um "social-liberal" ou um "liberal-socialista". Buscava uma alternativa às duas igrejas que dominaram as correntes políticas do Século XX (marxismo x liberalismo), e esta alternativa deveria ser essencialmente laica, desprovida de dogmas, independente e que salvasse, ao mesmo tempo, os valores da liberdade e da igualdade.

Em sua visão, seria possível pensar um socialismo que fosse indissociável da democracia. Acreditava que o liberalismo, na acepção política do termo, poderia mover-se para um socialismo, entendido como complemento da democracia puramente liberal; e, da mesma forma, o socialismo poderia ir em direção ao liberalismo, entendido como um socialismo que não seja antiliberal. Nas palavras de Tosi, é como se o pensador de Turim reconhecesse que não consegue se decidir entre socialismo e liberalismo ${ }^{53}$. Esse caminho do meio, na busca de uma síntese e de uma convergência, constitui a sua força intelectual,

52 TOSI, Giuseppe. 10 Lições sobre Bobbio. São Paulo (SP), Editora Vozes, 2016, pag. 51.

${ }^{53}$ TOSI, Giuseppe. 10 Lições sobre Bobbio. São Paulo (SP), Editora Vozes, 2016, pag. 68 
embora possa ser também a sua debilidade perante os críticos. Para Tosi, o dilema de Bobbio se assemelha, no Brasil, ao de Carlos Nelson Coutinho, para quem "não há socialismo sem democracia." 54

Ocorre, contudo, que a semelhança entre o dilema de ambos (socialismo $\mathrm{x}$ democracia), é apenas aparente. Embora os pressupostos possam ser parecidos, a diferença está no fato de que, enquanto para Coutinho a solução está numa reformulação e atualização da perspectiva revolucionária marxista, para o segundo a saída encontra-se no seu abandono definitivo (o abandono da perspectiva marxista) em favor do reformismo gradual. Bobbio não é, definitivamente, um pensador da ruptura, mas sim um defensor da reforma gradual.

A tarefa de estruturar o poder pressupõe a estruturação do direito, consoante uma abordagem filosófica da justiça. Bobbio acredita que a democracia possa fomentar um Estado que esteja consoante aos princípios de justiça. Justiça a quem o Estado deve servir.

Nessa busca, as dicotomias ajudam a sinalizar os caminhos possíveis. E neste ponto nos deparamos com um paradoxo: embora o resultado da obra de Bobbio seja assistemático, seu método de trabalho passa, necessariamente, pela rigorosa sistematização do pensamento filosófico, a partir dos clássicos até os modernos. Assistemático no resultado de sua produção. Sistematizador no método empregado. E é Santillán quem identifica esta aparente contradição:

"No que diz respeito aos autores clássicos, os ensaios Marx, o Estado e os clássicos e Marx, Weber e os clássicos são representativos do espírito sistematizador de Bobbio. Este espírito se manifesta no método comparativo, no modo como confronta as teses de um pensador com as de outros". 55

Em Direito e Estado no Pensamento de Emanuel Kant, Bobbio reitera, logo de início, que a doutrina do Estado Liberal e democrático, que surgiu como reação ao Estado absoluto no século XVIII, está ligada às teorias do contratualismo, este consolidado nas duas revoluções inglesas do século XVII. Sustenta, na sequência, de forma categórica, que a característica desse Estado liberal moderno não é tanto a maneira pelo qual é justificado e instituído, mas os limites que lhe são impostos. E complementa:

\footnotetext{
${ }^{54}$ Obra cit., pags 68 e $69 .$.

55 SANTILLÁN, José Fernandez. Norberto Bobbio, o Filósofo e a Política/Antologia. Rio de Janeiro (RJ), Contraponto Editora, 2016, pag. 30.
} 
"A prova dessa afirmação é que, com a própria teoria do fundamento, foram justificados na história do pensamento político tanto estados absolutos quanto limitados, tanto os estados autocráticos quanto democráticos. O que vale para os fins da busca que aqui estamos conduzindo não é tanto que o poder soberano tenha este ou aquele fundamento, mas que não possa abusar da própria força e que os direitos dos cidadãos sejam garantidos contra a prepotência de quem manda". ${ }^{56}$

Em suma, importa mais como se governa do que quem governa. No desdobramento dessa máxima, não seria então exagero dizer que estudamos as formas de governo, para entender a sua essência.

${ }^{56}$ BOBBIO, Norberto. Direito e Estado no Pensamento de Emmanuel Kant. Brasília (DF), Editora Universidade de Brasília, 1984. 


\section{O pensamento jurídico - A estruturação do poder}

Norberto Bobbio é frequentemente classificado como um pensador pertencente à corrente jusfilosófica denominada "Escola Analítica", para alguns também conhecida como "Positivismo Analítico". Contudo, suas posições são significativamente integradoras, diluídas ou mesmo matizadas, o que faz com que não seja assim tão fácil identificá-lo com essa corrente ou com qualquer outra. Não restam dúvidas, porém, que desde a década de 1950 a sua produção intelectual representa de forma nítida um programa de reformulação do estudo do direito, até então perdido, na esfera acadêmica, num estéril debate entre jusnaturalismo e positivismo, como bem aponta Tercio Sampaio Ferraz Junior. ${ }^{57}$

Bobbio admite o direito como um meio, desde que a justiça seja o seu fim. Em sua Teoria do Ordenamento Jurídico enfrenta desde o início a problemática da norma e da sanção. A sanção, em sua abordagem reflexiva e não sistêmica, é definida como um expediente através do qual se busca, num sistema normativo, "salvaguardar a lei da erosão contrária", conforme ressalta Ferraz Junior. ${ }^{58}$ A norma jurídica, desta forma, busca a sua própria unidade e coesão dentro do sistema. A sanção é uma resposta externa à violação. A sanção jurídica é a resposta externa e institucionalizada. Mas Bobbio procura evitar uma dicotomia rígida entre "ser" e " dever ser", admitindo que o critério de sanção externa e institucionalizada está referido não a cada norma em particular, mas ao ordenamento como um todo. Portanto, tudo dependerá do ponto em que nos colocaremos na pirâmide jurídica.

As sanções são postas pelo ordenamento jurídico para obter um dado comportamento humano que o legislador considera desejável. O direito como meio, a justiça, aí representada pela coesão social que a norma posta potencializa ou propicia, como o fim. O Estado, que estabelece a norma, está, desta forma, a serviço do bem maior. Para que o Estado cumpra essa função e alcance o seu fim, porém, alguns parâmetros e pressupostos devem ser observados. É nesse ponto

\footnotetext{
${ }^{57}$ BOBBIO, Norberto. Teoria do Ordenamento Jurídico. Brasília (DF), Editora Universidade de Brasília, 10a Edição, pág. 7.

${ }^{58}$ Obra cit., pág. 9.
} 
que a Teoria do Direito imbrica com a Filosofia Política, e o pensamento de Bobbio converge.

As sanções nem sempre são negativas, no sentido da repressão. As sanções positivas são recompensas. A distinção sempre foi admitida na literatura jurídica e filosófica, mas, segundo Bobbio, uma concepção típica do século XIX marginalizou durante muito tempo entendimento das sanções positivas, que nada mais são que estímulos que o Estado estabelece para os seus cidadãos, tendo em vista o progresso e a coesão social. A sanção é positiva, por exemplo, quando o ordenamento jurídico estabelece um recolhimento menor de imposto predial para o contribuinte que reformar a fachada de seu imóvel, contribuindo para a estética urbana, ou quando garante abatimento de tributos para quem apoia financeiramente obras sociais.

Neste sentido, o caráter parafiscal da tributação revela uma maior intervenção estatal na economia, reduzindo a distância entre a esfera do interesse econômico privado e a do interesse político, necessariamente voltado ao público, entre a condição do burguês e a do cidadão, típica do século XIX. Não é exagero dizer que a importância que o mundo jurídico dava à sanção negativa reproduzia, assim, uma visão hegeliana de cisão entre sociedade civil e Estado. É indiscutível que hoje, mesmo nas nações denominadas "capitalistas", nas quais as regras de mercado se sobrepõem ao planejamento estatal central na condução econômica, o Estado tem uma função que vai muito além da protetora-repressora. Ferraz Junior comenta:

"Ora, neste contexto, uma teoria jurídica da sanção, limitada ao papel das sanções negativas e, pois, ignorando o papel assistencial, regulador e empresarial do Estado, estaria destinada a fechar-se num limbo, entendendo mal, porque entendendo limitadamente, a relação entre o direito, o Estado e a sociedade". ${ }^{59}$

A teoria jurídica meramente de sanção ignora o papel interventor do Estado, equívoco que Bobbio não apenas evita como denuncia em sua Teoria do Ordenamento Jurídico. O maior grau de intervenção não vai, de forma alguma, significar menor um grau de liberdade dos indivíduos. Embora isso, isoladamente, dependendo do ordenamento e do Estado, possa vir a acontecer, não é algo automático e, na maioria das vezes, o que se dá é justamente o oposto. Sim,

\footnotetext{
${ }^{59}$ Obra cit., pág. 12
} 
porque o ordenamento do Estado moderno, ao produzir sanções positivas, colocase em linha com a "autonomia da vontade". De antemão, Bobbio ressalta que, nas sanções positivas, como se tratam de pensamentos permitidos, o agente é livre para fazer (tem a faculdade de fazer ou não fazer), ou seja, pode valer-se de sua própria liberdade. Estamos, assim, diante de um Estado que, aliado ao seu papel coativo e repressor, exerce também a função promocional, voltado para "o aumento e o aperfeiçoamento dos meios de socialização e de condicionamentos coletivos", como sinaliza Ferraz Junior. ${ }^{60}$ Mas o que são normas jurídicas e o que é um ordenamento jurídico? Bobbio responde:

"(...) as normas jurídicas nunca existem isoladamente, mas sempre em um contexto de normas com relações particulares entre si (e essas relações serão em grande parte objeto de nossa análise). Esse contexto de normas costuma ser chamado de 'ordenamento jurídico'. E será bom observarmos, desde já, que a palavra 'direito', entre os seus vários sentidos, tem também o de 'ornamento jurídico', por exemplo, nas expressões 'Direito Romano', 'Direito Canônico', 'Direito italiano', ['Direito brasileiro'] etc." 61

A norma jurídica era a única perspectiva através do qual o direito era estudado no passado, e o ordenamento jurídico, conforme os ensinamentos de Bobbio, era apenas um conjunto de normas, mas não um objeto autônomo de estudo, com os seus problemas particulares e diversos. Só se pode falar em direito onde haja um complexo de normas formando um ordenamento, e desta forma o direito não é norma, mas um conjunto coordenado de normas. Uma norma jurídica não se encontra jamais só, mas está sempre ligada a outras normas com as quais forma um sistema normativo. Contudo, existem problemas conexos com a existência do ordenamento jurídico.

Uma definição do Direito só será possível se nos colocarmos do ponto de vista do ordenamento jurídico. Bobbio elenca quatro critérios para classificar o Direito: 1) critério formal; 2) critério material; 3) critério do sujeito que põe a norma; 4) critério do sujeito ao qual a norma se destina. O critério formal relaciona-se ao aspecto estrutural da norma, que pode ser positiva ou negativa, categórica ou hipotética, geral (abstrata) ou individual (concreta). Bobbio entende que, embora essa classificação seja válida para efeito didático, a rigor, no que toca o critério formal, será a segunda distinção (categórica ou hipotética) a mais válida

\footnotetext{
${ }^{60}$ Obra cit., pág. 15

${ }^{61}$ Obra cit., pág. 19.
} 
para a compreensão da norma e do direito, uma vez que praticamente toda regra pressupõe condições. Exemplos: se matou, será punido; se sofreu ofensa, será indenizado; se investiu, receberá os dividendos, ou arcará com o prejuízo.

Pelo critério material, evidentemente, entende-se o conteúdo do Direito, mais precisamente das normas que compõe o ordenamento. $\mathrm{O}$ objeto da regulação são todas as ações possíveis do homem. Por essas ações possíveis Bobbio entende aquelas que não são nem necessárias, no sentido de inerentes à natureza (como, por exemplo, respirar), ou impossíveis, posto que há ações que não estão ao alcance do ser humano, não importa o seu esforço. O professor de Turim faz esse esclarecimento aparentemente óbvio para salientar que uma norma que proíba uma ação necessária (exemplo: "é obrigatório que todo recém-nascido passe a respirar") ou ordene uma ação impossível (exemplo: "todo cidadão maior de 18 anos deve voar batendo os braços") é inútil.

A clareza dessas definições e distinções nos permite perceber que não raro o legislador estabelece normas que são impossíveis ou naturalmente necessárias, o que nos remete novamente à questão de que maneira como se governa (e aqui o verbo governar empregado no sentido lato, abrangendo não apenas o Poder Executivo, mas também o Legislativo, porque formula e debate as leis) é tão relevante quanto quem governa. Pelo conteúdo das normas, identifica-se como quem governa, efetivamente, governa: se bem ou mal, se democraticamente ou de forma autocrática, se com razoabilidade ou com demagogia, se com racionalidade econômica ou com voluntarismo, e assim por diante.

Quanto ao critério do sujeito que põe a norma, consideram-se jurídicas as normas que são postas pelo poder soberano, aquele, nas palavras de Bobbio, "acima do qual não existe, num determinado grupo social [nação, país, Estado, unidade federada], nenhum outro, e que, como tal, detém o monopólio da força". ${ }^{62}$ Mais uma vez aqui nos deparamos com a questão precedente: importa saber, no juízo de valor, como um governo governa, e não apenas quem governa. Mais do que isso, é preciso reconhecer que, se é verdade que um ordenamento jurídico é definido através da soberania, é também verdade, seguindo os passos de Bobbio, que a soberania em uma determinada sociedade se define através do ordenamento jurídico. De qualquer forma, a teoria do direito como regra coativa e

\footnotetext{
${ }^{62}$ Obra cit, pág. 25.
} 
a teoria do direito como emanação do poder soberano são convergentes. Poder soberano e ordenamento jurídico são dois conceitos que se referem um ao outro.

"Dizer que a norma jurídica é a emanada do poder soberano equivale a dizer que a norma jurídica é aquela que faz parte de um determinado ordenamento. A soberania caracteriza não uma norma, mas um ordenamento; caracteriza a norma apenas enquanto ela é considerada como parte do ordenamento". ${ }^{63}$

O quarto e último dos critérios é aquele do ponto de vista do sujeito ao qual a norma é destinada. Bobbio faz a ressalva de que dizer que uma norma jurídica é dirigida aos súditos é algo inconcludente, porque vago. Para ele, jurídica é a norma seguida da convicção ou crença de sua obrigatoriedade. E, para avaliar a efetiva juridicidade de uma norma, é preciso examinar o ordenamento que a compreende. Explica que aquilo que comumente chamamos de direito é mais uma característica de certos ordenamentos normativos do que de certas normas. Assim, o problema de definição do direito se torna o problema de definição de um ordenamento. Mesmo partindo de uma norma, pretendendo entender o fenômeno do Direito, encontrar-se-á um ordenamento. Assim, acrescenta o professor de Turim que, para definir a norma jurídica, bastará afirmar que a norma jurídica é aquela que pertence a um ordenamento jurídico, transferindo manifestamente o problema da determinação do significado de jurídico da norma para o ordenamento. Na sequência, percebemos que somente a partir de uma teoria do ordenamento o fenômeno jurídico pode ser perfeitamente explicado e compreendido. Na visão de Bobbio, na análise do fenômeno, não se pode permitir que a norma abrace o ordenamento.

Sobre a definição específica de direito, Bobbio afirma, de forma preliminar, que o direito pressupõe uma organização, isto é, um completo sistema normativo, já que sanção jurídica é tão somente a institucionalizada. Mas há normas sem sanção, como vimos no caso das normas positivas. Porém, aqui, quando falamos de sanção organizada como aspecto constitutivo do direito, não estamos nos referindo às normas em particular, mas ao ordenamento normativo tomado em seu conjunto. Portanto, adverte Bobbio: "(...) dizer que a sanção organizada distingue o ordenamento jurídico de qualquer outro tipo de

\footnotetext{
${ }^{63}$ Obra cit, pag. 26.
} 
ordenamento não implica que todas as normas daquele sistema são sancionadas, mas somente que o são em sua maioria". ${ }^{64}$

Um dos principais desafios da teoria jurídica é especificar o momento em que uma norma consuetudinária (decorrente dos costumes) não jurídica distinguese de uma norma consuetudinária jurídica, ou, simplificando, quando uma norma do costume torna-se uma norma jurídica propriamente dita. Para Bobbio, o problema é insolúvel, não tão relevante, e por isso o melhor caminho a seguir é apenas dizer que uma norma dos costumes torna-se jurídica quando passa a fazer parte de um ordenamento. Por conseguinte, o problema a que a teoria deve se ater é "quais são os procedimentos através dos quais uma norma consuetudinária vem a fazer parte do ordenamento jurídico?". Por fim, Bobbio deixa claro que o termo "direito" indica um tipo de sistema normativo, jamais um tipo de norma.

Deparamo-nos aqui com outro desafio, representado pela pluralidade de normas. Se ordenamento é um conjunto de regras, para que haja um ordenamento é preciso que concorram várias normas - teoricamente, ao menos duas. Mas essa certeza por si só não esclarece o problema. Para desenhar a gênese de um ordenamento, devemos ter em mente que ele jamais poderá conter normas únicas em que: 1) tudo é permitido; 2) tudo é proibido; e 3) tudo é obrigatório. Ora, se tudo é permitido, não estamos diante de um Estado civil (o que implica a existência de um ordenamento), mas do estado de natureza no melhor sentido hobbesiano, do homem como lobo do homem. O estado de natureza é a negação do ordenamento. Por outro lado, se tudo é proibido, a vida do homem - e, por extensão, a vida em sociedade - torna-se impossível. Para completar, se tudo é obrigatório, o que se terá é um conflito permanente e infinito de normas, o que também inviabilizará a convivência coletiva.

Percebe-se, assim, nas lições de Bobbio que é impossível um ordenamento que regule todas as ações possíveis com uma única modalidade normativa (ou tudo permitido, ou tudo proibido, ou tudo obrigatório). A exceção estaria em uma espécie de ordenamento muito simples, como por exemplo, aqueles que consideram como pré-requisito para ingressar numa irmandade ou clube apenas uma obrigação, como fazer uma doação ou ter publicado uma obra. Reconhecida a pluralidade de normas e a diversidade dos tipos de normas de um ordenamento,

\footnotetext{
${ }^{64}$ Obra cit. pag.29.
} 
fica claro que os principais problemas conexos com a sua existência decorrem da relação das diversas normas entre si. $\mathrm{O}$ que nos permite concluir que um ordenamento, para ser coeso e ter eficácia, deve prescrever a hierarquia que disciplina as suas normas. Sem hierarquia, a unidade estaria em risco. Outra questão é das antinomias jurídicas, i.e., a contradição entre normas, algo que também precisa ser previsto e equacionado por regras do próprio ordenamento. Da mesma forma, para ser completo, um ordenamento não pode deixar lacunas, o que significa dizer que não pode deixar conflito ou problema jurídico sem solução, e as regras para tanto devem ser igualmente previstas pelo próprio ordenamento. Somente assim um ordenamento poderá ser um sistema, característica que lhe deve ser intrínseca.

A hipótese de um ordenamento com apenas duas normas, como referido acima, é puramente um exercício acadêmico. As normas são muitas e variadas, derivam de várias fontes. A complexidade é tão maior quanto maior foram as necessidades de uma sociedade de satisfazer a regulação de todas as regras de conduta. O Poder soberano, portanto, reconhece normas já feitas na mesma medida em que institucionaliza a produção de normas novas. Têm-se, em consequência, vários tipos de fontes do direito. Mas, em tese, pode haver um poder originário, que seria a fonte das fontes. Esse poder é aquele que, além do qual, não há outra instância que possa justificar o ordenamento jurídico.

Trazendo a reflexão para o mundo prático, podemos dizer que o poder original é o Legislativo e que ele, em conjunto com o órgão de cúpula do poder Judiciário (Corte Constitucional, Supremo Tribunal, Corte Suprema), afere e convalida o ordenamento. A sociedade civil sobre a qual nasce um ordenamento não é uma sociedade natural. O poder originário, uma vez constituído, cria ele mesmo novas centrais de produção para satisfazer a necessidade de uma normatização sempre atualizada, atribuindo a diferentes órgãos, em diferentes esferas, a competência de fazer normas integradoras subordinadas às legislativas. Cabe ao Poder Judiciário, fiscalizar a fundamentação e a validade dessas normas, bem como a sua correta aplicação. Nas palavras de Bobbio:

"É impossível que o Poder Legislativo formule todas as normas necessárias para regular a vida social; limita-se então a formular as normas genéricas, que contêm somente diretrizes, e confia aos órgãos executivos [por meio de medidas, decretos, portarias, normas 
complementares, regulamentos etc], que são muitos e numerosos, o encargo de torná-las exequíveis".

Bobbio explica que, de acordo com o pensamento jusnaturalista, o poder civil originário forma-se a partir de um estado de natureza por meio de um procedimento característico do contrato social. Esclarece que há duas formas de conceber esse contrato social. Pela primeira, a hobbesiana, os que firmam o contrato renunciam completamente aos seus direitos naturais dando surgimento a um poder civil sem limites - razão pela qual o pensamento de Hobbes é associado ao Estado absoluto, ou, mais precisamente, à monarquia absoluta. A segunda hipótese é a de Locke, pela qual, os contratantes firmam o contrato social para preservar os seus direitos, entre os quais, o direito à vida, à liberdade e à propriedade.

Como vemos, a distinção é relevante, pois na primeira hipótese o direito natural desaparece completamente, enquanto na segunda ele é assegurado pelo direito positivo. $\mathrm{O}$ direito positivo, nesta abordagem, seria então um instrumento para garantir o direito natural, o que é um aparente paradoxo. Por essa razão, os juristas positivistas que aceitam a primeira visão serão levados a estabelecer o princípio da autolimitação do Estado. Dessa forma, explicam porque, num ordenamento centralizado e que se proclama originário, como é o Estado moderno, existem poderes normativos descentralizados e/ou suplementares. Já na segunda teoria, a soberania já nasce limitada, pois o direito natural originário não é completamente suplantado pelo direito positivo. Segundo Bobbio, nessas duas hipóteses é possível ver claramente representados e racionalizados os dois processos de formação de um ordenamento jurídico e a estrutura complexa que deles deriva. Ele acrescenta:

"Ao falarmos de uma complexidade do ordenamento jurídico, derivada da presença de fontes reconhecidas e de fontes delegadas, acolhemos e reunimos numa teoria unitária do ordenamento jurídico seja a hipótese dos limites externos, seja a hipótese dos limites internos" ${ }^{65}$

Na sequência de sua Teoria do Ordenamento Jurídico, Bobbio fala em tripartição clássica das normas, sendo essas as das normas imperativas, as das normas proibitivas e a das normas permissivas. E afirma que as fontes do Direito

\footnotetext{
${ }^{65}$ Obra cit., pag.40.
} 
são aqueles fatos ou atos dos quais o ordenamento jurídico faz depender a produção de normas jurídicas. Assim, mais uma vez vemos que o ordenamento jurídico, além de regular o comportamento das pessoas e das instituições públicas e privadas, regula também o modo pelo qual se devam produzir as regras. Em outras palavras, o ordenamento jurídico regula a própria produção normativa, havendo normas de comportamento ao lado de normas de estrutura.

A partir da tripartição, temos normas de variados tipos: as que mandam ordenar, as que proíbem ordenar, as que permitem ordenar, as que mandam proibir, as que proíbem proibir, as que proíbem permitir, as que mandam permitir e as que permitem permitir. A construção do ordenamento se faz de forma escalonada, sendo a norma fundamental, expressa na Constituição, o termo unificador de todas as demais que compõem o ordenamento. Está claro que a estrutura é hierárquica, do contrário os conflitos entre as regras seriam permanentes. $\mathrm{O}$ contrato da esfera privada é uma regra de conduta que deve estar adstrita a outras normas reguladoras do ordenamento. Todas as normas e regras estão sujeitos a limites.

Os Poderes da República limitam-se entre si. De cima para baixo, o poder normativo será sempre mais circunscrito, com restrições relativas não apenas ao conteúdo como a forma. E por essa razão temos limites materiais e limites formais. O primeiro diz respeito ao conteúdo da norma que o poder inferior está capacitado a emanar; o segundo refere-se ao modo como esta norma deve ser emanada pelo poder inferior. Quando, por exemplo, uma Constituição atribui aos seus cidadãos o direito à liberdade religiosa, limita o conteúdo normativo do legislador ordinário. Quando as normas constitucionais estabelecem a maneira como as instituições deverão funcionar, estamos diante de limites formais. Mas a norma fundamental se limita à norma fundamental? Bobbio responde da seguinte forma:

"Dado o poder constituinte como poder último, devemos pressupor, portanto, uma norma que atribua ao poder constituinte a faculdade de produzir normas jurídicas: essa norma é a norma fundamental. (...) É uma norma ao mesmo tempo atributiva e imperativa, segundo se considere do ponto de vista do poder ao qual dá origem ou da obrigação que dele nasce. Pode ser formulada da seguinte maneira: 'O poder constituinte está obrigado a estabelecer normas obrigatórias para toda a coletividade' ou 'A 
coletividade é obrigada a obedecer às normas estabelecidas pelo poder constituinte." 66

Assim, podemos considerar que todo o poder jurídico é produto de uma norma jurídica, e que o poder constituinte é ele mesmo um poder jurídico. Daí decorre que, se uma norma jurídica é válida, significa que é obrigatório conformar-se com ela. E sabemos que uma norma é válida quando ela pode ser reinserida na norma fundamental, i.e., se ela está consoante a norma fundamental. Há uma secular discussão em torno do fundamento que Bobbio, talvez não com completo sucesso, tenta enfrentar. Ela parte do pressuposto de que a norma fundamental não tem fundamento porque do contrário não seria norma fundamental. Dá várias hipóteses como resposta. Todas elas, sem exceção trazem no seu âmago um caráter teológico ou ideológico. Se a norma fundamental é a derradeira fonte última do poder, ela poderia ser, pelas hipóteses, proveniente: de Deus, da Lei Natural (razão), do Contrato Social (acordo originário). Assim, o problema da existência de um ordenamento é deslocado para a sua justificação.

Para não deixar a questão em aberto, Bobbio a sintetiza dizendo que o poder originário, para efeito de estudo do ordenamento e do exame de sua estruturação, é o conjunto das força políticas que "num determinado momento histórico tomaram o domínio e instauraram um novo ordenamento jurídico". ${ }^{67}$

Deparamo-nos aí novamente com a convergência entre direito e Estado, e entre direito, Estado e poder. Mais do que isso: percebemos a co-relação entre a estruturação do Estado e o seu fim, a justiça, que é formulada em função de um outro ente: a coletividade (ou sociedade civil). A força é o instrumento necessário do poder, mas isso não significa que ela seja o fundamento. A força é necessária para o exercício do poder, mas não para justificá-lo. A força é aceitável como instrumento da realização do direito, tendo em vista a justiça. Porque um ordenamento jurídico só existirá enquanto for eficaz.

A definição de direito, portanto, descola-se claramente da de justiça. A justiça é mais do que o direito positivo, aquele posto pelo Estado. A justiça é o direito como "deve ser". Ou seja, justiça difere de direito. A avaliação de um Estado e o juízo de valor sobre um regime, um governo ou um governante, portanto, se "bom" ou "mau", deve se voltar para o exame do grau de justiça que

\footnotetext{
${ }^{66}$ Obra cit., pág. 59.
}

${ }^{67}$ Obra cit., pág. 65. 
ele pode produzir em prol de seu objeto: conjunto de cidadãos. Se ficarmos apenas na justificação jurídica do direito, ignorando a sua legitimação moral, o que teremos é a expressão dos mais fortes, não dos mais jutos.

Por ser um positivista analítico, Bobbio se distingue de outros positivistas, em especial, Kelsen, para quem o Direito é, a rigor, um ordenamento coercitivo, ou seja, um ordenamento que regula normas de coerção. Trata-se de uma definição extremamente limitativa.

"(...) A juridicidade de uma norma se determina não através de seu conteúdo (nem pela forma, ou pelo fim, e assim por diante), mas simplesmente através do fato de pertencer a um ordenamento, fato este que, por sua vez, se determina remontando da norma inferior à superior, até a norma fundamental. Se considerarmos um ordenamento jurídico em seu conjunto, é certamente lícito dizer que um ordenamento se torna jurídico quando se vêm formando regras pelo uso da força (passe-se da fase do uso indiscriminado à do uso limitado e controlado da força); mas não é igualmente lícito dizer que, em consequência disso, que um ordenamento jurídico é um conjunto de regras para o exercício da força. As regras para o exercício da força são, num ordenamento jurídico, aquela parte de regras que serve para organizar a sanção e, portanto, para tornar mais eficazes as normas de conduta e o próprio ordenamento em sua totalidade. O objetivo de todo legislador não é organizar a força, mas organizar a sociedade mediante a força".

A assertiva final do parágrafo acima (de que o objetivo é organizar a sociedade mediante a força), não deve dar margem à ideia de totalitarismo, muito menos ser confundida com uma defesa oblíqua do autoritarismo. Na verdade, tal princípio visa justamente o inverso: impedir que o uso da força seja indiscriminado. Eis o papel do Estado civil, cuja característica é o ordenamento jurídico, em oposição ao estado de natureza. O Estado totalitário decorre do uso desmedido da força, da sua aplicação equivocada, bem como de ordenamentos equivocados, ou mal estruturados, ou, junto a tudo isso, da disposição de atores políticos para tanto. Autoritário (totalitário) ou democrático, o ordenamento terá sempre a força (coerção) como atributo intrínseco

Para compreender melhor essa distinção, recorremos à leitura de Dicionário de Política. Nele Bobbio explica que o adjetivo autoritário e o substantivo autoritarismo que dele deriva empregam-se em três contextos: a estrutura dos sistemas políticos (aqui, portanto, compreendido o arcabouço legal do Estado e de suas instituições), as disposições psicológicas a respeito do poder e as ideologias políticas. 
"Nesse contexto, a oposição e a autonomia dos subsistemas políticos são reduzidos à expressão mínima e as instituições destinadas a representar a autoridade de baixo para cima ou são aniquiladas ou substancialmente esvaziadas." 68

A força é condição necessária para um regime totalitário, mas não é a condição suficiente, e tampouco significa que o reconhecimento do uso da força como traço inerente ao Estado civil expresse também o reconhecimento ou a legitimação do autoritarismo. Em Direito e Poder, ao discorrer sobre o valor moral do Estado, a sua justificação ética e a sua existência de fato, Bobbio joga com esses conceitos e indaga, em tom retórico: "Então, só pelo fato de eu afirmar que o Estado soviético é um Estado, faço a apologia da força?"69 Neste ponto, Bobbio retoma o conceito kantiano de que o direito está relacionado à faculdade de coagir, e isso independe se estamos ou não nos referindo a regimes totalitários. Significa que a rigor direito implica, necessariamente, coação.

68 BOBbIO, Norberto; MATTENTI, Nicola; PASQUINO, Gianfranco. Dicionário Político. Brasília (DF), Editora Universidade de Brasília, 1983, pág. 94.

${ }^{69}$ BOBBIO, Norberto. Direito e Poder. São Paulo (SP). Editora UNESP, 2007. 


\section{Positivismo e jusnaturalismo - Uma questão do direito}

Para Bobbio, o que o estudo do chamado direito natural nos mostra é que as máximas de justiça, quando são universais, tornam-se fórmulas vazias, preenchíveis com qualquer conteúdo. Esse é o ponto de partida de sua crítica ao jusnaturalismo, sem que com isso caia na armadilha de um positivismo radical. O jusnaturalismo atrela à validade da lei ao seu valor, ou seja, ao sentido de Justiça. Mas Bobbio adverte que, quando preenchemos o conteúdo de uma máxima supostamente universal, porque a entendemos como natural, na verdade a estamos abastecendo com nossa bagagem ideológica. E isso não foi colhido na natureza. Ao extremo, podemos dizer que o conceito de justiça é ideológico. Quando afirmamos "é preciso dar a cada um segundo a sua necessidade" ou "a cada um segundo o seu trabalho", estamos instituindo regras que derivam de uma compreensão ideológica do mundo, mais precisamente de ideologias políticas. Essa ideologia, por sua vez, tem uma influência histórica.

O exame das concepções positivista e jusnaturalista de direito passa a ser relevante para a compreensão do Estado, para a sua fundamentação jurídica e sua justificação ética. Está claro que normas jurídicas não representam ideais eternos de justiça. Como referido na Introdução desta dissertação, na Teoria do Estado, e para uma Teoria do Estado, voltada para a análise de sua estruturação, a Teoria Geral do Direito é importante na medida em que tem a função de fixar as condições de juridicidade dos institutos jurídicos. Para avançar nessa discussão, que, como já dito, talvez tenha sido o fio condutor e integrador que Bobbio não reconheceu à sua obra, devemos entender o que foi a Teoria Pura do Direito elaborada por Kelsen. ${ }^{70}$

Segundo Bobbio, a Teoria Pura do Direito sempre combateu em duas trincheiras: de um lado, contra o direito natural; de outro, contra a sociologia. A polêmica contra o direito natural foi conduzida em nome da objetividade da ciência (jurídica), a qual, como salienta Bobbio, "tem a tarefa de conhecer a realidade e não de avaliá-la". ${ }^{71} \mathrm{O}$ direito natural, por sua vez, é o campo de todas

\footnotetext{
${ }^{70}$ KELSEN, Hans. A Teoria Pura do Direito. São Paulo-SP, Martins Fontes, 1999.

${ }^{71}$ BOBBIO, Norberto. Direito e Poder. São Paulo (SP). Editora UNESP, 2007, pág. 23.
} 
as ideologias que, ao longo dos tempos, pretendem avaliar o direito positivo para afirmar a conformidade de certos ideais de justiça, seja a partir de doutrinas conservadoras ou de doutrinas revolucionárias. Segundo Bobbio, ao agir contra a Teoria Pura do Direito, o direito natural exprime valores subjetivos e até irracionais, os quais, por isso mesmo, são irredutíveis a análises científicas. Em síntese, sem objetividade, não há ciência. Levando a análise de Bobbio ao extremo, podemos dizer que, se o direito é aquele de acordo com o concebido pelos jusnaturalistas, é tudo menos ciência.

Por outro lado, o embate contra a sociologia deu-se em torno da distinção entre a esfera do ser, à qual pertencem os fenômenos sociais, e a esfera do dever ser, à qual pertence o direito. Como vimos no capítulo precedente, o Direito é um complexo de normas (ordenamento), uma estrutura "qualificadora da realidade social". Por isso, esclarece o pensador de Turim, o direito deve ser estudado não como a sociologia, que se volta para o exame da realidade social com o método casual próprio das ciências sociais, mas como uma ciência particular, que não pretende explicar os fatos, sejam eles físicos, psíquicos ou sociais, mas, sim, explicar as normas - as normas que qualificam os fatos de acordo com a estruturação jurídica de cada sociedade. Por isso, Bobbio afirma que o direito é uma ciência sui generis.

Dessa forma, a Teoria Pura do Direito tem duas pretensões: ser ciência (e não ideologia); e ser a ciência própria do objeto específico a que se dirige (o direito). Estabelece-se, portanto, como única ciência do direito e também como uma Ciência verdadeira, porque livre de ideologias políticas. Por essa abordagem, Kelsen sofreu críticas tanto dos juristas católicos, típicos representantes do jusnaturalismo, quanto dos juristas marxistas, defensores da sociedade contra o formalismo. Enquanto os defensores do direito natural amparam-se na metafísica, os sociólogos ou promotores da visão sociológica do direito apoiam-se na experiência (abordagem empírica). Ambos atribuem à Teoria Pura do Direito kelseniana o erro capital de impor ao jurista (e à própria Justiça) "comportar-se como um frio intérprete da norma positiva, não importando o valor ético dessa norma"72. Isso significaria, segundo eles, que o jurista se transforma, com essa postura, em colaborador de qualquer regime, por mais repulsivo que possa ser.

\footnotetext{
${ }^{72}$ Obra cit., pág. 25.
} 
Mas é aí que entra uma distinção fundamental feita por Kelsen e reiterada por Bobbio: aquela entre o valor do direito e validade.

São dois, portanto, os problemas existentes: 1) se a norma é justa; 2) se a norma existe, ou seja, se de fato é válida. A Teoria Pura do Direito não elimina nem um problema, nem o outro. O que ela elimina é a confusão entre ambos. Bobbio traz luz à reflexão:

"Essa distinção serve exclusiva (e acrescentamos: superiormente) para não confundir duas ordens de problemas, dando desse modo à ciência do direito aquilo que é dela, e à Filosofia (se pensarmos que a Filosofia é, em última análise, a elaboração e a justificação de um sistema de valores) o que é da Filosofia." 73

O confronto entre jusnaturalistas e positivas se exacerbou na primeira metade do século XX, chegando ao paroxismo com a publicação da Teoria Pura do Direito de Kelsen, mas, na verdade, trata-se de uma discussão conceitual que remonta à Antiguidade, invadindo o pensamento jurisfilosófico da Idade Média. Nos duelos entre Sócrates e Sofistas, já encontramos as distinções entre aquilo que é por natureza (physis) e aquilo que é por convenção ou posto pelos homens (thésis), como bem aponta Bobbio na Introdução de O Positivismo Jurídico Lições de Filosofia do Direito. ${ }^{74} \mathrm{O}$ professor de Turim lembra que Aristóteles fazia de forma clara a distinção entre o Direito Natural, que seria aquele que está em toda a parte, e o Direito positivo, que seria aquele que tem eficácia apenas nas comunidades políticas singulares em que é posto.

Assim, pela visão aristotélica, enquanto o direito natural prescreve ações cujo valor não depende do juízo que sobre elas tenha o sujeito (pois existem independentemente do fato de parecerem boas ou más), o direito positivo, inversamente, estabelece ações que, antes de serem reguladas, podem ser cumpridas de um modo ou de outro, mas, uma vez reguladas pela Lei, precisam ser cumpridas de forma imperativa tal como estão prescritas. Bobbio resgata a distinção feita por Aristóteles no Capítulo VII, do Livro V da Ética a Nicômaco:

"Da justiça civil uma parte é de origem natural, outra se funda na lei. Natural é aquela justiça que mantém em toda a parte o mesmo efeito e não depende do fato que pareça boa a alguém ou não; fundada na lei é

\footnotetext{
73 Obra cit., pág. 26.

74 BOBBIO, Norberto. Positivismo Jurídico - Lições de Filosofia do Direito. São Paulo (SP), Ícone Editora, 2006.
} 
aquela, ao contrário, de que não importa se suas origens são estas ou aquelas, mas sim como é, uma vez sancionada". ${ }^{75}$

Ainda referindo-se a Aristóteles, Bobbio lembra, para frisar a distinção, o exemplo dado pelo filósofo de Estagira: antes da existência de uma lei ritual, é indiferente sacrificar a uma divindade uma ovelha ou duas cabras; depois que passa a existir uma lei que ordena sacrificar uma ovelha, isto se torna obrigatório. No direito romano, a distinção também está presente, com o jus civile e o jus gentium/jus naturale. O primeiro limita-se a um determinado povo, enquanto o segundo não tem limites. O primeiro é posto pelo povo (sociedade); o segundo, pela naturalis ratio. Assim, pela distinção feita na Antiguidade, temos que o direito natural é universal e imutável, ao passo que o civil (contrário ao estado de natureza) é particular, tanto no tempo quanto no espaço.

Se o direito natural estabelece aquilo que é bom, o direito civil dispõe sobre aquilo que é útil. O juízo correspondente ao primeiro, explica Bobbio, funda-se num critério moral. Já o juízo relativo ao segundo baseia-se, queiramos ou não, num critério econômico ou utilitário. Na Idade Média, o direito positivo era claramente entendido como aquele posto pelos homens, enquanto o natural seria aquele além deles, ou, mais precisamente, acima deles. Pensadores canônicos, como Santo Tomás, preferem apenas denominar, na distinção, lex naturalis x lex humana, uma vez que consideram que a lex divina (que abarca a lex naturalis) é, ela também, positiva.

Mas aqui estamos nos atendo às definições históricas do direito, usadas como referência por Bobbio em Positivismo Jurídico. Na análise contemporânea, essas distinções se diluem, pois, o que o positivismo jurídico veio demonstrar, em última análise, foi que aquele direito que entendíamos como natural era ele também produção humana.

De qualquer forma, a breve incursão histórica clarifica os conceitos e nos ajuda a prosseguir no exame da antítese entre jusnaturalismo e positivismo jurídico. O exame traz de forma inerente uma abordagem do direito que leva em consideração a estruturação do Estado como poder. Bobbio admite que a visão jusnaturalista de que toda norma jurídica é válida apenas se for justa teve a finalidade prática bem definida de fazer com que o soberano se guiasse por

\footnotetext{
${ }^{75}$ Obra cit., pág. 16.
} 
princípios de humanidade e justiça. Da mesma forma, dava aos súditos um pretexto para recusar a obediência à Lei imposta contra a sua consciência moral ou religiosa (como se a norma não fosse válida).

"Mas essas finalidades - por mais nobres que se pretendam, nos Estados democráticos, onde existem outros meios mais eficazes para garantir a correspondência das leis às exigências da justiça - não cancelam minimamente o fato de que as leis de qualquer ordenamento tenham sido e sejam válidas e eficazes embora injustas, e que o jurista se quiser ser um inquiridor dos fatos e não um moralista ou um pregador - tenha o dever de distinguir as normas válidas das inválidas, independentemente do fato de elas repugnarem, ou não, à sua consciência e à de outros." 76

O contraponto entre juízo de valor e juízo de fato pode espelhar o confronto entre jusnaturalismo e positivismo. Equivaleria à questão referente à diferença entre juízo sobre a justiça de uma norma e o juízo sobre a validade da mesma norma. O primeiro juízo é de valor; o segundo, juízo de fato. Que Brutus tenha matado César é um juízo de fato; que a morte de César seja uma ação boa ou má é um juízo de valor. E neste ponto indaga Bobbio, de forma contundente: "Que diríamos do historiador que sustentasse que não é verdade que Brutus matou César, pois não é bom que o tivesse feito". ${ }^{77}$

Os jusnaturalistas argumentariam que, no campo da humanidade, os juízos de valor tendem a influir sobre os comportamentos, alterando-os para um sentido correto. Afirmando que tal lei é injusta, os jusnaturalistas não estariam dizendo que ela não existe ou que não é válida, mas simplesmente que não deveria existir. $\mathrm{E}$, ao afirmar que uma lei não deveria existir, porque não é justa, estariam estimulando os cidadãos a descumpri-la, fazendo com que, num certo momento, ela deixe de fazer parte do ordenamento. Mas da posição metodológica da Teoria Pura do Direito, pela qual o jurista tem a tarefa de ocupar-se do direito efetivamente válido e não do direito justo, não se extrai, necessariamente, a proposição segundo a qual "todas as leis, enquanto tais, devem ser obedecidas".

Segundo Bobbio, essa conclusão, premeditada, não é tão dedutível assim e, nem Kelsen a faz de forma clara. O que é, sim, evidente do ponto de vista positivista, é que o jurista que deseja fazer ciência e não obra de apologia política ou filosófica, está adstrito ao estudo das leis em seu caráter de exequibilidade,

\footnotetext{
${ }^{76}$ BOBBIO, Norberto. Direito e Poder. São Paulo (SP). Editora UNESP, 2007, pág. 27.

${ }^{77}$ Obra cit., pág. 28.
} 
independentemente de sua correspondência com os ideais de justiça, sejam eles quais forem. Trata-se de uma proposição de ordem lógico-metodológica que caracteriza a postura do cientista do direito distinguindo-o do filósofo. A outra proposição, "de que todas as leis devem ser obedecidas enquanto leis" é, ela também, de ordem ética e política, e se refere ao indivíduo perante as leis de seu país. Na primeira posição, estamos no campo de uma concepção da ciência do direito; na segunda, no de uma concepção de justiça. Para Bobbio, o legalismo jurídico é relevante para a sociedade, mas trata-se igualmente de uma doutrina ético-política.

Em outras palavras, a Teoria Pura do Direito é uma teoria do conhecimento do direito. Já a concepção legalista é, sim, e sem qualquer dúvida, uma teoria da justiça. Kelsen, explica Bobbio, se limita a dizer que o direito existe, independentemente do fato de ser ou não justo, quando a norma, além de válida, também eficaz (princípio da efetividade). Ao contrário de um jusnaturalista típico, como Hobbes, que reduz a Justiça à força, jamais poderia se extrair da concepção kelseniana que o direito é justo enquanto comando. $\mathrm{O}$ direito existe enquanto for comando, mas não é justo por essa razão. Kelsen não trata da justificação moral do direito e, por consequência, também não pode tratar da construção de um Estado ideal, como o fez - por que não o dizer? - Hobbes. O Estado ideal e a justiça que dele deve emanar são objetos da Filosofia Política e da Filosofia do Direito, não da Ciência do Direito.

Bobbio explica que toda a pesquisa kelseniana baseia-se em uma distinção consciente, e cada vez mais reiterada e elaborada, entre ciências normativas e ciências naturais. A Ciência Pura do Direito é, como vemos, uma ciência objetiva, indiferente aos valores, neutra. Contudo, Bobbio também identifica no sistema kelseniano, por mais rigoroso que seja, traços valorativos.

"Por mais que a Teoria Pura do Direito seja um sistema rigoroso, revela aqui e ali algumas falhas das quais transparece o momento ideológico do homem Kelsen. Certamente a certeza não é uma ilusão, mas um valor [um valor na medida em que decorre de fatos objetivos]. Considerando-a como ilusão, Kelsen mostra claramente rechaçá-la como valor e aceitar o seu valor oposto, saindo de sua neutralidade de teórico puro, ao passo que é verdade ao contrário, ou seja, que da estrutura normativa do ordenamento jurídico não se pode extrair argumento em favor da certeza, nem tampouco do valor contrário. A certeza maior ou menor, ou a equidade maior ou menor, dependerão, em cada ordenamento, das normas particulares que, tendo por base as diversas ideologias 
orientadoras, regulam as relações entre órgãos legislativos e executivos, e estabelecem maiores ou menores vínculos à atividade do juiz". ${ }^{78}$

A análise da oposição entre jusnaturalismo e positivismo requer uma abordagem, ainda que superficial, da norma, do sistema normativo e da jusriprudência. Ciência normativa é uma expressão ambígua, que dá margens a disputas verbais improdutivas, segundo Bobbio. Ele esclarece que a categoria "normativo" distingue as Ciências Jurídicas das Ciências Sociais. A Ciência Jurídica é descritiva enquanto descreve aquilo que é, mas, para tanto, vale-se, necessariamente de determinado sistema normativo. A jurisprudência, por sua vez, atua diretamente no sistema jurídico, além de fazer parte dele. Já a metajurisprudência vai determinar o que a jurisprudência deve ser.

Tanto a jurisprudência quanto a meta-jurisprudência podem desenvolver uma ação de conservação e inovação, a primeira, ensina Bobbio, em relação ao sistema jurídico vigente, a segunda em relação à tendência predominante da jurisprudência e, assim, por via indireta, também sobre o sistema jurídico vigente. A jurisprudência é ela também fonte do direito. E é ciência normativa enquanto tem a ver com normas. Um sistema jurídico é dinâmico. O jurista, ao criar jurisprudência, fabrica o seu próprio objeto - e também instrumento - de trabalho.

"As normas são investigadas, interpretadas, encontradas para serem adotadas; à elaboração segue-se a fase de uso. Podem elas ser adotadas de vários modos, mas, levando em conta o fim específico do trabalho do jurista, que é o de atribuir direitos e deveres no âmbito de um determinado sistema normativo, a distinção mais própria, também neste caso, é entre uso direto e indireto. Direto é o uso visando à aplicação; indireto o uso para fins de sistematização". ${ }^{79}$

A partir de uma visão positivista, a análise de um ordenamento é estrutural e funcional, mas não pode ser relativa à finalidade. Quando Kelsen afirma que o Estado é o próprio ordenamento jurídico vai além de Weber, para quem o poder é completamente legalizado. Bobbio esclarece que, enquanto o primeiro se propõe a elaborar uma teoria geral do Estado, o segundo descreve um tipo ideal de Estado. Pela concepção de Kelsen, o que distingue o Estado, enquanto ordenamento jurídico, de outros ordenamentos, como aqueles das sociedades paraestatais ou o ordenamento internacional (convenções e acordos), é o grau de organização ou a

\footnotetext{
${ }^{78}$ Obra cit., pág. 51.

${ }^{79}$ Obra cit. pág. 71
} 
existência de órgãos que trabalham segundo as regras de divisão de trabalho para a produção e aplicação das quais ele é constituído. Fica claro, assim, para Kelsen a importância dos grandes aparatos administrativos na formação do Estado moderno, no que seu pensamento coincide com o de Weber.

Coincide também o pensamento de ambos quando Weber afirma, sobre o direito, que existe um ordenamento jurídico quando se forma, num determinado grupo social, um aparato coercitivo. Para um positivista, o problema do fundamento se resolve, como já vimos, na validade das normas. O direito regula, assim, a sua própria produção. No fenômeno da normatização, o direito não tem fundamento senão no próprio direito. A justificação axiológica, na visão positivista preconizada por Kelsen e, em grande medida, assimilada por Bobbio, não é um problema. Alguém está em condições de produzir direito à medida que tem o poder ou a força de fazê-lo. A produção de normas jurídicas é o efeito do exercício de um poder. $\mathrm{O}$ direito não é declarado, mas posto. A sua existência está condicionada a uma força capaz de impor ou autorizar comportamentos.

$\mathrm{Na}$ co-relação entre direito, poder e força, pela concepção estritamente positivista, temos então, resumidamente, o seguinte: a) a própria definição do direito como força; b) a redução do Estado a ordenamento jurídico (contrariando aqueles que fazem do Estado uma força ou um poder fora do direito); c) a distinção entre validade e eficácia, pela qual o chamado "poder estatal" é a validade de um ordenamento jurídico efetivo; d) o próprio conceito de norma fundamental, cuja função é transformar "poder em direito"; e e) a distinção entre direito privado e direito público, pela qual Kelsen refuta a teoria que considera um verdadeiro direito somente o direito privado e interpreta o direito público como a expressão do direito estatal.

Bobbio, cabe novamente ressaltar, não é um positivista puro. Ele não reduz o Estado ao ordenamento jurídico. O que ele afirma - e neste ponto está em consonância com Kelsen - é que a crítica política fica vedada à Ciência Jurídica positiva, sendo de competência da Filosofia moral e, como acrescenta Luigi Ferrajoli, "sobretudo da moral e da política, que guiam os juízos e os comportamentos de cada um de nós". ${ }^{80}$ Para Bobbio, a positividade não é por si só

${ }^{80}$ BOBBIO, Norberto. Jusnaturalismo e Positivismo Jurídico. São Paulo (SP). Editora UNESP, 1996, pág. 32. 
um valor. Ele quer dizer com isso que o direito positivo não se manifesta em relação ao conteúdo das prescrições. Portanto, ele é positivista à medida que assume diante do direito uma atitude isenta de valoração, objetiva, eticamente neutra. Assume como critério para distinguir uma regra jurídica de uma não jurídica sua derivação de fatos verificáveis.

Em Jusnaturalismo e Positivismo Jurídico, assim como em Positivismo Jurídico - Lições de Filosofia do Direito, que, somadas à Direito e Poder, compõem o cerne do pensamento filosófico-jurídico de Bobbio, tal abordagem do direito é assumida e desenvolvida na dissecação dos conceitos. Porém, a tarefa é realizada com um permanente olhar crítico para o pensamento de Kelsen, que é a via teórica pela qual as três obras percorrem.

Ao discorrer sobre a abordagem positivista, Bobbio percorre ao mesmo tempo a análise da visão jusnaturalista. Ao estabelecer esse cenário de contraponto entre uma e outra abordagem, definindo seus limites disciplinares e também apontando as suas influências, traça um "mapa do saber filosófico-jurídico", como apropriadamente aponta Ferrajoli, pelo qual é possível examinar conceitos relacionados à Filosofia da Justiça, à Teoria do Direito e à Sociologia Jurídica. Bobbio apresenta, dessa forma, as perspectivas do direito.

O Poder jurídico é, portanto, o poder de produzir e aplicar normas. Os conceitos de norma e poder, neste sentido, remetem um ao outro. É inerente ao positivismo jurídico considerar como conceito fundamental da Teoria do Direito o conceito de produção jurídica. $\mathrm{O}$ positivismo jurídico distingue-se do jusnaturalismo exatamente por essa razão: para o jusnaturalismo, o direito é algo dado, e o nosso trabalho é descobri-lo, revelá-lo e aplicá-lo; para o positivismo, o direito é um produto artificial, convencional e se trata de interpretá-lo, tendo igualmente em mente que a sua interpretação é, ela também, uma obra de criação e contínua recriação. O positivista não enxerga o direito natural de outra forma do que um mero produto da vontade humana, o que equivale a dizer que, para ele, não há nada além do direito positivo.

Como não poderia deixar de ser, o poder social é sempre poder organizado. O poder do Estado é, por consequência, o poder organizado pelo direito positivo. Deparamo-nos com círculo que se retro-alimenta: sociedadeEstado-poder. Aquilo que se chama poder estatal é a validade de um efetivo ordenamento estatal. Uma vez deixada de lado a teoria jusnaturalista, segundo a 
qual direito é aquilo que é justo, não encontramos outra solução a não ser afirmar que direito é aquilo que é de fato observado. A norma fundamental transforma o poder em direito. Bobbio reconhece que, embora Kelsen tenha reiterado o caráter científico de sua obra, os seus estudiosos não podem renunciar completamente a tentar entender o sentido ideológico de suas formulações, buscando interpretar as suas opções políticas. O professor de Turim refuta, porém, a tese de que, sob a Teoria Pura do Direito, esteja a ideologia do Estado burguês:

"Diria antes que, atrás da tese da primazia do direito sobre o poder, primado que se manifesta na suposição da norma fundamental, existe, mesmo que inconsciente, e também expressamente desmentido [desmentido indiretamente pela própria proposta teórica de Kelsen], o ideal de Estado de Direito, isto é, do Estado em que, para me exprimir com uma fórmula tradicional, usada durante séculos pelos legistas, 'lex facit regem' e não 'rex facit regem "'. ${ }^{81}$

Para salientar o caráter ideológico do jusnaturalismo, Bobbio esclarece que para os jusnaturalistas, a liberdade, entendida como independência, foi considerada um direito natural, até que Kant fez dela o Direito fundamental. ${ }^{82}$ Lembra, sem disfarçar certo sarcasmo, que Aritóteles considerava perfeitamente natural a escravidão, porque "a natureza tinha feito que houvesse homens naturalmente senhores e homens naturalmente escravos". Uma natureza tão condescendente e tão volúvel que permitiu que teóricos do Estado liberal exaltassem a neutralidade da liberdade e que filósofos de uma cultura escravocrata justificassem a escravidão, e que Locke propusesse uma teoria segunda a qual a propriedade privada era natural porque decorria de um ato natural.

Ainda com uma boa dose de ironia, Bobbio lembra que, em resposta a Locke, Rousseau, "o verdadeiro fundador da sociedade civil", teria dito: "o primeiro que, tendo cercado um terreno, se lembrou de dizer: 'isso é meu', e encontrou pessoas bastante simples para acreditar nele". ${ }^{83}$ Curioso é notar, nos passos de Bobbio, que duas tradições paralelas e opostas apelam para a Lei da Natureza em oposição ao positivismo: de um lado, o pensamento liberal burguês, que desemboca nas declarações de direitos do final do século XVIII (Declaração de Direitos), que dirá que a propriedade privada é um direito individual, inviolável

\footnotetext{
${ }^{81}$ Obra cit, pág. 167.

${ }^{82}$ BOBBIO, Norberto. Jusnaturalismo e Positivismo Jurídico. São Paulo (SP). Editora UNESP, 1996, pág. 205

${ }^{83}$ Obra cit., pág. 205
} 
e sagrado e, de outro, o pensamento utopista socialista, de Campanella a Winstanley, que apela para o "código de natureza" a fim de demonstrar que o único regime que a natureza prescreve é o da comunhão de bens. Esses confrontos nos permitem ver claramente que o jusnaturalismo é, na verdade, uma teoria da moral. E que é um mito achar que a natureza - ao menos aquela aplicada à vida social e que rege a conduta dos homens - é sempre benéfica. Ao pretender deduzir o valor do fato, ou seja, aquilo que acha que "deve" acontecer daquilo que realmente acontece, o jusnaturalista ilude-se. Bobbio quer dizer com isso que o jusnaturalista faz o exame de acordo com o seu ideal, ou de acordo com aquilo que deveria ser o ideal, e não exatamente com base naquilo que aconteceu ou está estabelecido.

A separação do direito como é e do direito como deve ser é, como percebemos, a forma com a qual colocamos o positivismo em oposição ao jusnaturalismo, que resolve a validade do Direito na Justiça, i.e., a partir de uma interpretação ideológica e moral. A essa acepção o positivismo opõe o princípio da relatividade dos valores. Desta forma, em resumo, no seu sentido mais puro, o positivismo jurídico como teoria é uma forma de pensar o direito, também denominada por Bobbio de "estatal-legalista" 84 , caracterizada tanto por uma afirmação do direito do Estado sobre qualquer outro ordenamento, como por uma afirmação de preeminência da Lei sobre as outras fontes do direito.

Para Bobbio, portanto, nessa acepção, positivismo é mais do que um método: não se restringe a um modo de se estudar o direito, constituindo, na verdade, um conjunto complexo e sistemático de asserções em torno do direito. Quanto ao jusnaturalismo, Bobbio sustenta que o direito natural "não o é" no sentido estrito do termo, pois não deriva da natureza. Constitui, assim, uma abordagem valorativa da norma jurídica. O que falta à Lei Natural seria justamente o que constitui elemento característico do direito, ou seja, a sua efetividade.

$\mathrm{Na}$ conclusão desse capítulo, convém discorrer sobre a utilidade da Filosofia do Direito, tema do qual Bobbio trata no Capítulo 5, Parte I de Jusnaturalismo e Positivismo Jurídico. Ao realçar a importância da Filosofia do Direito, o pensador de Turim descola-se de uma posição meramente positivista -

\footnotetext{
${ }^{84}$ Obra cit., pág. 186.
} 
ou de jurista que reconhece o positivismo como método científico - desvelando a sua dimensão de verdadeiro filósofo. Ao fazer isso, indiretamente, acentua a distinção entre a Ciência Jurídica e a Filosofia do Direito:

"Não me parece tarefa muito difícil mostrar a utilidade das pesquisas mencionadas no tópico precedente [que trata de princípios da Justiça, entre ouros temas] para a formação de um jurista. (...) Pois bem, a Teoria do Direito ou do Ordenamento Jurídico elabora os conceitos mais gerais, que são comuns a todos os ordenamentos jurídicos e necessários para a compreensão do fenômeno jurídico em qualquer ambiente social em que ele se manifeste. Além disso, insere o sistema jurídico entre outros sistemas normativos, como a moral e o costume, e, portanto, ajuda o jurista a sair de seu isolamento. A Teoria da Justiça, ao chamar a atenção para os valores que inspiram esta ou aquela regra jurídica, põe o jurista em contato com as matrizes culturais das quais deriva todo ordenamento jurídico e, portanto, também aquele ao qual ele está particularmente voltado, além de torná-lo mais sensível à compreensão dos vários condicionamentos ideológicos do sistema jurídico que lhe cabe interpretar. Enfim, a Teoria da Ciência Jurídica oferece ao jurista a possibilidade de encontrar uma razão para os métodos empregados em seu trabalho, para os instrumentos de pesquisa e de construção, para a variada natureza e eficácia dos argumentos usados, e com o tempo pode contribuir para o refinamento e o aperfeiçoamento da Jurisprudência. De resto, o bom jurista [grifo nosso] é tão pouco hostil à Filosofia do Direito que, como já disse, a melhor Filosofia do Direito, sobretudo no campo da Teoria do Ordenamento Jurídico e da Teoria da Ciência Jurídica, foi, grosso modo, feita pelos juristas. (...) a tarefa da Filosofia do Direito, do ponto de vista didático, é romper os diques que mantêm as disciplinas jurídicas tradicionais no lago artificial de um sistema positivo" 85 .

${ }^{85}$ Obra cit., páginas 69-71. 


\section{A Era dos Direitos - O progresso para o melhor}

Em a Era dos Direitos ${ }^{86}$, logo na abertura da obra, Bobbio estabelece que direitos do homem, democracia e paz são três momentos necessários do mesmo movimento histórico. Direitos humanos e democracia se articulam, no interior de cada sociedade nacional, para criar as condições necessárias para uma paz em âmbito global. Há um nexo entre democracia e direito, e entre esses dois conceitos e a razão e a paz. Não pode haver democracia sem uma razão que estabeleça um Direito justo. Uma paz global depende, na melhor acepção kantiana, de regimes nacionais racionais, ou seja, voltados para a Justiça, em prol da coletividade. Por óbvio, Bobbio reconhece que até pode haver direito sem democracia, mas não democracia sem direito.

Nos elos que se encadeiam, a democracia requer uma construção jurídica, que estabeleça normas para o jogo político, enquanto a razão é o instrumento necessário não apenas à interpretação do direito, mas à sua formulação, tendo em vista a sociedade que se pretende projetar e preservar. $\mathrm{O}$ arcabouço jurídico elaborado em consonância com a razão é o pressuposto de uma sociedade onde impera o ideal de justiça. Quando dizemos que a razão é necessária, estamos também reconhecendo que é necessária porque o direito, ao contrário do que os jusnaturalistas advogam (e aí reside a crítica de Bobbio, conforme vimos no capítulo precedente) não é um dado da natureza, mas, sim, um produto do gênio humano. Se é uma construção do homem, será, necessariamente, fruto da prática política, a qual também a influenciará, como um círculo que se retro-alimenta.

Em a Era dos Direitos, retoma novamente o exame do jusnaturalismo, mas vai além, estabelecendo, com nítida inspiração em Kant que um dos problemas para a Paz Perpétua é um sistema mundial heterogêneo, no qual nem todos os estados são democráticos. Também inspirado em Kant, Bobbio deixa transparecer que a Era dos Direitos, ou melhor, a progressão dos Direitos Humanos desde o século XVIII até os nossos dias é um indício de que a humanidade, de fato, progride para o melhor. Não é taxativo quanto à resposta para a pergunta "está a

${ }^{86}$ BOBBIO, Norberto. A Era dos Direitos. São Paulo (SP), Editora Elsevier, 2004. 
humanidade progredindo rumo ao melhor?", adiando uma resposta definitiva. Porém, a sua análise evolutiva acerca dos Direitos Humanos dá indiretamente a resposta.

Esclarece, na Introdução da obra, que o "reconhecimento e a proteção dos direitos do homem estão na base das constituições democráticas modernas". Porque, justifica, sem direitos do homem reconhecidos e protegidos, não há democracia; sem democracia, não existem condições mínimas para a solução pacífica dos conflitos.

Para Bobbio, está claro, os direitos humanos são históricos, no sentido de que sua dinâmica acompanha a trajetória da humanidade. Se há mais direitos hoje, e eles são mais protegidos, é porque há progresso moral. E aqui, nos deparamos mais uma vez com uma postura positivista ante o jusnaturalismo.

"Do ponto de vista teórico, sempre defendi - e continuo a defender, fortalecido por novos argumentos - que os direitos do homem, por mais fundamentais que sejam, são nascidos de certas circunstâncias, caracterizados por lutas em defesa de novas liberdades contra velhos poderes, e nascidos de modo gradual, nem todos de uma vez, e nem de uma vez por todos" .87

Afirma que a liberdade religiosa é um efeito das guerras de religião; que as liberdades civis, da luta dos parlamentos contra os soberanos absolutos; as liberdade política e as liberdades sociais, do nascimento, crescimento e amadurecimento do movimento dos trabalhadores assalariados, dos camponeses com pouca ou nenhuma terra, dos pobres que exigem dos poderes públicos não só o reconhecimento da liberdade pessoal e das liberdades negativas (o direito de se abster de fazer algo), mas também a proteção do trabalho contra o desemprego, de amparos sociais e assim sucessivamente. A evolução, neste sentido, parecia ser notória e permanente até o momento em que Bobbio publicou A Era dos Direitos $^{88}$. Depois dos direitos sociais, que são considerados de segunda geração, vieram os de terceira geração, ainda muito heterogêneos e não totalmente

\footnotetext{
${ }^{87}$ BOBBIO, Norberto. A Era dos Direitos. São Paulo (SP), Editora Elsevier, 2004, pág. 5.

${ }^{88}$ Nota: A partir das duas últimas décadas do Século XX e mais nitidamente a partir dos anos 2010, pressões voltadas para a redução de direitos, sobretudo nas esferas trabalhista e previdenciária, foram registradas em todo o Ocidente. Contudo, tais pressões, embora possam ter logrado êxito na redução de direitos pontuais, seriam vistas, sob a ótica do pensamento bobbiano, como oscilações ou contracorrentes dentro de um processo que, no longo prazo, continua a apontar para a evolução dos direitos. Idealmente, a busca dos direitos persiste, ainda que enfrentando retrocessos. Foi próprio Bobbio quem ressaltou que o mais difícil nos dias de hoje é a defesa dos direitos, não propriamente a sua elaboração e conceituação.
} 
assimilados, como, por exemplo, o direito a viver num ambiente saudável. Eles nasceram todos de uma vez e evoluem em razão direta da evolução da própria humanidade. E os de quarta geração, como os relativos à segurança genética.

Direitos humanos são também fins que moralmente merecem ser perseguidos. A despeito disso, Bobbio rechaça a ideia de se promover, do ponto de vista filosófico e acadêmico, um fundamento absoluto para os direitos humanos. Adverte que qualquer fundamento absoluto, além de ser uma ilusão, corre sempre o risco de se tornar um pretexto para se defender posições conservadores. Lembra, inclusive, que, com o fenômeno da multiplicação dos direitos, todos eles com as suas próprias justificativas sociais, econômicas, étnicas, religiosas e culturais, deparamo-nos hoje com o desafio de solucionar o conflito entre direitos - o que comprova que os Direitos Humanos não podem ter um fundamento único e absoluto.

Bobbio alerta que o maior problema dos Direitos Humanos hoje é o seu reconhecimento, mas, sim, a sua proteção e preservação. Mostra assim que o problema é mais político do que filosófico, e político no sentido universal, não se restringindo a um determinado país ou sociedade. Não se trata de justificá-los, mas de garanti-los e defendê-los. E exatamente por essa razão, acredita que o problema dos fins não pode ser dissociado do problema dos meios. Se a questão é instrumental, ela é jurídica.

$\mathrm{Na}$ verdade, duas seriam as dificuldades, uma colocando-se em sequência à outra: a primeira de natureza eminentemente jurídico-política; a segunda substancial, inerente ao conteúdo. Bobbio elenca três aspectos dos Direitos Humanos: a promoção, o controle e a garantia. A promoção visa a estimular os Estados a tutelarem os Direitos Humanos e a aperfeiçoá-los. Controle refere-se ao conjunto de medidas que os organismos internacionais mobilizam para verificar se os Direitos Humanos estão sendo implementados e protegidos, e em que grau isso está ocorrendo. As atividades de garantia, por fim, significam a estruturação de uma efetiva estrutura de tutela internacional. Um dos maiores problemas dos Direitos Humanos reside no fato de que não se pode instituir um novo Direito em relação a um determinado segmento de pessoas sem, necessariamente, reduzir ou mesmo suprimir direitos de outras categorias de pessoas.

Deparamo-nos com um aparente conflito entre liberdade e igualdade, ou entre liberdade e justiça social. Bobbio considera irrecorrível reconhecer que as 
sociedades reais hoje existentes "são mais livres na medida em que menos justas e mais justas na medida em que menos livres"89. E chama de "liberdades" os direitos que são garantidos enquanto (ou quando) o Estado não intervém. No exame da questão, denomina ainda "poderes" quando os direitos exigem uma intervenção estatal para a sua efetivação. Liberdades e poderes, como se percebe, nem sempre são complementares e muito frequentemente tornam-se incompatíveis. Exemplifica afirmando que o poder de comprar automóveis diminui na mesma razão que a liberdade de circulação é reduzida. E vai além:

"Outro exemplo, um pouco menos banal: a extensão do direito social de ir à escola até os catorze anos suprimiu, na Itália, a liberdade de escolher um tipo de escola e não outro". ${ }^{90}$

O que Bobbio tenta dizer com isso é que a sociedade histórica em que vivemos, ou seja, a sociedade que gradual e paulatinamente foi construindo os seus direitos paralelamente à sua dinâmica política e cultural, esta sociedade, que tem como característica - adverte ele - uma organização cada vez maior em vista da eficiência, é uma sociedade em que a cada dia "adquirimos uma fatia de poder em troca de uma falta de liberdade". Fica claro aqui que, também no plano teórico, quando se examinam os Direitos Humanos e os seus tipos, a oposição entre duas concepções de mundo: a socialista e a liberal. É apontando a distinção patente entre as duas visões que o "pensador da convergência" vai mais uma vez tentar estabelecer uma perspectiva.

Afirma, em tom crítico, que a história submeteu a uma dura prova os regimes que representavam as duas concepções. O que podemos então esperar dos dois tipos de regime não é, portanto, uma síntese definitiva, mas, no máximo, um compromisso (ou seja, uma síntese, mas provisória). E conclui, de forma realista, quase beirando um pessimismo que estaria na contramão de sua crença no progresso da humanidade:

"A efetivação de uma maior proteção dos Direitos do Homem está ligada ao desenvolvimento da civilização humana. (...) A quem pretenda fazer um exame sem preconceitos do desenvolvimento dos direitos humanos depois da Segunda Guerra Mundial, aconselharia esse salutar exercício: ler a Declaração Universal e depois olhar em torno de si. Será obrigado a reconhecer que, apesar das antecipações iluminadas dos filósofos, das corajosas formulações dos juristas, dos esforços dos

\footnotetext{
${ }^{89}$ Obra cit., pág. 42

${ }^{90}$ Obra cit. pág. 42.
} 
políticos de boa vontade, o caminho a percorrer ainda é longo. E ele terá a impressão de que a história humana, embora velha de milênios, quando comparada às enormes tarefas que estão diante de nós, talvez tenha apenas começado". ${ }^{91}$

Ainda que se dobrando à realidade dos fatos e expressando um certo descontentamento em relação ao que foi feito até aqui - reconhece ele, muito pouco -, tendo em vista a magnitude do problema, Bobbio atribui aos Direitos Humanos um valor profético, deixando clara a sua crença na evolução civilizatória. Num paralelo, os Direitos Humanos representam para Bobbio um balizador ou termômetro dessa evolução, assim como a Revolução Francesa representou para Kant "uma disposição moral da humanidade". Não é por outra razão que o pensador de Turim, em A Era dos Direitos, recorre ao filósofo de Königsberg para estruturar a suas teses a cerca dos Direitos Humanos.

"Se o gênero humano está em constante progresso para o melhor". Explica Bobbio que, por constituição civil Kant entendia uma constituição em harmonia com os direitos naturais do homem. Mas aqui "direitos naturais" entendidos não no estrito sentido do jusnaturalismo, mas, sim, como o direito de todo homem de obedecer apenas à Lei de que ele mesmo é legislador. A liberdade como autonomia, significando poder de legislar para si mesmo. Didaticamente, repassa as asserções apodíticas expressas na Metafísica dos Costumes (obra escrita na mesma época da Revolução Francesa). Lembra Bobbio que, uma vez entendido o direito como a faculdade moral de obrigar os outros, o homem tem direitos inatos e adquiridos; e o único direito inato, ou seja, transmitido ao homem pela natureza e não por uma autoridade constituída, é a liberdade. A liberdade, afirma Bobbio, interpretando Kant, "é a independência em face de qualquer constrangimento imposto pela vontade do outro, ou mais uma vez, a liberdade como autonomia". ${ }^{92}$

Não deixa de ser notável que um filósofo do Direito, que se alinha formalmente no campo do positivismo jurídico (ainda que um positivismo jurídico distante do radicalismo de Kelsen) repita, sem cerimônia, que a liberdade é um "direito inato". O próprio Kant, vale dizer, segundo Bobbio, não era um jusnaturalista, pois, como vimos no Capítulo V, estabeleceu a Liberdade como fundamento, não como obra da natureza. O fato é que Bobbio assimila "o sinal premonitório". E declara:

\footnotetext{
${ }^{91}$ Obra cit., pág. 44.

92 Obra cit., pág. 49.
} 
"Inspirando-me nessa extraordinária passagem de Kant [em que o filósofo fala da 'liberdade como autonomia'], exponho a minha tese: do ponto de vista da Filosofia da História, o atual debate sobre os direitos humanos - cada vez mais amplo, cada vez mais intenso, tão amplo que agora envolveu todos os povos da Terra, tão intenso que foi posto na ordem do dia pelas mais autorizadas assembleias internacionais, pode ser interpretado como um 'sinal premonitório' (signum prognosticum) do progresso moral da humanidade". ${ }^{93}$

Progresso moral e progresso científico não se confundem. A consciência moral advém da constatação do sofrimento da humanidade. Encontramo-nos num mundo hostil, na melhor acepção hobbesiana. As regras são criadas para impedir que o homem seja o lobo do homem, num esforço para superar o mal, rumo ao bem. Assim surgiram O Código de Hamurabi, A Lei das doze Tábuas e Os dez mandamentos. Mas a História da Humanidade, essa humanidade hostil, é também uma História da Moral, ou, mais precisamente, a história da construção de uma moral. As grandes obras de moral são tratados sobre leis, sobre um conjunto de regras que, ao longo dos tempos, vão estabelecendo de que forma o homem pode agir melhor para viver harmonicamente (se é possível chegar a tanto!) em coletividade.

Nessa dinâmica histórica, a figura deôntica originária, observa Kant, não é o direito, mas o dever. A função primária das Leis é comprimir, não libertar. A liberdade, nessa abordagem histórica, antes de ser um valor moral, é uma conquista histórica - assim como o serão todos os demais direitos que vieram na sequência e aqueles que ainda estão por vir ou estão por ser criados. O avanço é reformador, e independe de uma ideia revolucionária.

A relação política por excelência é a relação entre governantes e governados. Direito e dever são faces da mesma moeda. Historicamente, o ângulo de observação das leis muda de acordo com o sujeito: o ângulo dos governantes/legisladores e o dos governados. No progresso, temos então a passagem da ênfase dos deveres para os direitos. Também no campo dos Direitos Humanos, Bobbio fala na "revolução copernicana", que foi a inversão do ângulo de observação. O problema da moral precisou ser considerado não apenas do

\footnotetext{
${ }^{93}$ Obra cit., pág. 49.
} 
ponto de vista da sociedade, ou seja, do poder que impõe a norma em prol de uma coletividade, mas também daquele do indivíduo.

Bobbio é taxativo ao dizer que uma "revolução radical", no caso a copernicana, no sentido kantiano, de inversão do ângulo de observação, ou seja, a passagem do Código dos Deveres para o Código dos Direitos (a ótica dos indivíduos), pode ocorrer gradualmente, não precisa ser revolucionária. ${ }^{94} \mathrm{Nessa}$ avaliação, fica claro o espírito reformista do pensador Bobbio. O pensador de Turim, como já visto, não é um pensador da revolução. Se está claro que os Direitos Humanos são um fenômeno social, a secularização da ética cristã foi uma reviravolta no Ocidente: todos os homens são iguais ou são iguais enquanto filhos de Deus. O jusnaturalismo - e é Bobbio que o reconhece - foi o responsável por essa secularização.

"A doutrina filosófica que fez do indivíduo, e não mais da sociedade, o ponto de partida para a construção de uma doutrina da moral e do direito foi o jusnaturalismo, que pode ser considerado, sob muitos aspectos (e o foi certamente nas intenções de seus criadores), a secularização da ética cristã." 95

A partir daí, o ponto de vista do indivíduo diante do Estado tomou corpo. Os limites ao poder coercitivo foram estabelecidos, embora nem sempre respeitados. O Estado de Direito caracteriza-se hoje também e cada vez mais pelas garantias do indivíduo na esfera penal perante o poder constituído - e temos exemplos bem próximos de como a ofensa a essas garantias representam uma violência contra a democracia. As garantias individuais expressam o Estado democrático de direito tanto quanto outros institutos tradicionais, como liberdade de expressão, separação de Poderes, eleições diretas e voto universal. Bobbio lembra que foi somente durante o crescimento do Estado liberal e de direito, no século XIX, que se manifestou a tendência "a considerar a motivação política do ato violento contra as instituições de um Estado (particularmente de um Estado despótico e, enquanto tal, nem liberal nem de direito) com indulgência". Acrescenta Bobbio que durante séculos - sob a espécie de delito de lesa-majestade - foi julgado com a maior severidade. Hoje, afirma o pensador, diante da explosão

\footnotetext{
94 Obra cit., pág. 54.

95 Obra cit., pág. 54.
} 
do terrorismo político, "vai-se manifestando também uma tendência contrária nos Estados liberais e de direito, cuja expressão é a emanação de leis excepcionais".

De qualquer forma, para Bobbio, onde a trajetória da evolução parece de fato evidenciar avanços nos últimos séculos, é naqueles momentos onde há interdependência entre a teoria e a prática da tolerância. E isso acontece quando se consolida uma mentalidade que confia a sorte da humanidade mais às "razões da razão" que pode unir todos os homens do que aos impulsos da fé. Ressalta o pensador de Turim que foi esse espírito que deu origem aos Estados não confessionais ou neutros em matéria religiosa, e também mais neutros em matéria política.

"Deu origem também à chamada sociedade aberta, na qual a superação dos contrastes de fé, de crenças, de doutrinas, de opiniões, deve-se ao império da áurea regra segunda a qual minha liberdade se estende até o ponto em que não invada a liberdade dos outros, ou, para usar as palavras de Kant, 'a liberdade do arbítrio de um pode subsistir com a liberdade de todos os outros segundo uma lei universal' (que é a Lei da razão)". ${ }^{96}$

O homem não possui direitos preexistentes à instituição do Estado. É o dever, na origem da estruturação do Estado, que aglutina os homens em coletividade. Um grupo de indivíduos jamais poderia criar uma sociedade com base exclusivamente nos direitos - o dever é o que os une na origem. E onde houver primazia do direito não significa de forma alguma a eliminação do dever, pois direito e dever são dois termos correlatos. Não se pode afirmar um direito sem lembrar o dever do outro de respeitá-lo. Ressalta Bobbio que qualquer um que tenha tido maior intimidade com a história do pensamento político notará que o estudo da política sempre foi direcionado para dar maior destaque aos deveres do que aos direitos dos cidadãos.

Em Direito e Estado no Pensamento de Emmanue Kantl ${ }^{97}$, Bobbio faz longa incursão pelos conceitos de Liberdade e Justiça, novamente repassando os autores modernos. Não se afastando de seu característico método de apresentar ideias e conceitos opostos, com aproximações sucessivas, reafirma que Locke difere de Hobbes porque, enquanto para o primeiro o Contrato (pacto social)

\footnotetext{
${ }^{96}$ Obra cit., pág. 198.

${ }^{97}$ BOBBIO, Norberto. Direito e Estado no Pensamento de Emmanuel Kant. Brasília (DF),

Editora Universidade de Brasília, 1984
} 
visava a preservar direitos, para o segundo os homens renunciam aos seus direitos com o objetivo de estabelecer a paz (para prevenir a guerra de todos contra todos). Retoma neste ponto as doutrinas do jusnaturalismo, reiterando que elas dividemse em dois grupos: as que consideram que, na passagem do Estado de natureza para o Estado civil, estão extintos o direito natural, onde se alinham Hobbes e Rousseau, e as que, contrariamente, entendem que, nessa passagem, conserva-se o que há de melhor no Estado de natureza, ou seja a vida e a propriedade. O Estado civil daria assim eficácia ao estado de natureza e, nessa concepção, segundo Bobbio, estariam alinhados Locke e o próprio Kant. ${ }^{98}$

A análise da passagem do Estado de natureza para o Estado civil não deixa de ser relevante para a compreensão da evolução dos direitos. Kant é, na avaliação de Bobbio, um autor substancialmente liberal na linha do pensamento que forma a concepção política do Iluminismo, do qual seria, na opinião do professor de Turim, um dos teóricos mais coerentes. Para Kant, o direito privado passa a gozar de garantias no Estado civil que não tinha no Estado de natureza. Bobbio então vai adiante e afirma que o Estado civil nasce, portanto, não para anular o Direito natural, mas para possibilitar o seu exercício através da coação. E que, na visão de Kant, o Direito Civil não surge da antítese ao Direito Natural, mas para integrá-lo. O que muda na passagem não é a substância, mas a forma. De acordo com essa visão, o Estado não modifica os principais institutos do Direito privado que surgiram nas relações entre indivíduos no Estado de natureza, como a propriedade, a sucessão, o contrato etc. Na verdade, o Estado civil garante o exercício de institutos do Estado de natureza. Assim, pode-se dizer que o Estado civil recepcionou o Direito privado, entendido aqui como Direito Natural.

De acordo com as lições de Bobbio, para Kant, o homem deve sair do Estado de natureza, onde cada um segue o seu capricho, e unir-se a todos os outros, submetendo-se a uma coação externa publicamente legal. A constituição do Estado é, portanto, uma exigência moral. ${ }^{99}$ É um imperativo moral que o homem saia do Estado de natureza e ingresse no Estado Civil (jurídico), porque somente assim se promoverá uma justiça distributiva em substituição a uma justiça cumulativa. O Estado de natureza é injusto. Entra-se no Estado civil para que a própria liberdade possa coexistir com a dos outros.

\footnotetext{
${ }^{98}$ Obra cit. pág. 39.

${ }^{99}$ Obra cit., pág. 121.
} 
Contudo, a liberdade é um fim que deve prescindir da constituição do Estado. Antes do contrato social, que resgata o homem do estado de natureza, a liberdade já seria um valor a ser buscado pelo homem. O Estado não pode obrigar o indivíduo a ser feliz de acordo com as suas próprias diretrizes. ${ }^{100}$ Deve atuar de maneira a que o indivíduo posa realizar a sua própria felicidade. O dever moral de constituir um Estado - o Estado que garantirá mais tarde não apenas deveres, mas direitos, e tipos crescentes de direito - conduz também a um dever jurídico. Os deveres jurídicos, segundo Bobbio, distinguem-se dos deveres morais pela forma, não pelo conteúdo. Para aqueles que só entram no Estado civil pela força, este dever é legal, não moral.

A passagem de um estado a outro ocorre por meio do contrato social. Bobbio salienta que Kant acata a doutrina contratualista. O contrato original leva a uma Constituição civil universalmente jurídica. Kant, portanto, desloca o Contrato Social do fato histórico para o ideal da razão. Na análise de Bobbio, ao fazer isso, Kant retira do contratualismo qualquer ideia revolucionária. Neste sentido, Kant é um conservador, afirma Bobbio. ${ }^{101}$ E podemos dizer que, para Bobbio, os direitos - e a conquista de novos direitos - prescindem das revoluções. Embora possa advir na esteira delas, depende sobretudo da razão. Aqui nos deparamos com o espírito reformador e não revolucionário do pensador de Turim, para quem é possível aperfeiçoar a sociedade, progredindo no sentido da justiça social, por meio de melhorias graduais, sem necessidade de rupturas.

Na última página de A Era dos Direitos, afirma Bobbio: "se me perguntassem o que é necessário para se ter confiança [no progresso rumo ao melhor], eu voltaria às palavras de Kant: 'conceitos justos, uma grande experiência e, sobretudo, muito boa vontade'". ${ }^{102}$

No ensaio Direitos Humanos, publicado na coletânea Norberto Bobbio, o filósofo e o político - Antologia ${ }^{103}$, o professor de Turim lembra que a história profética ("outra ideia kantiana") ${ }^{104}$ não prevê, mas anuncia o futuro. E completa:

"(...) O debate atual sobre os direitos humanos é cada vez mais extenso, a ponto de parecer na ordem do dia dos mais prestigiosos tribunais internacionais [a

\footnotetext{
100 Obra cit., página 123.

101 Obra cit., pág. 129.

102 BOBBIO, Norberto. A Era dos Direitos. São Paulo (SP), Editora Elsevier, 2004, pág. $212 .$.

${ }^{103}$ SANTILlÁN, José Fernandez. Norberto Bobbio, o Filósofo e a Política/Antologia. Rio de Janeiro (RJ), Contraponto Editora, 2016.
} 
Corte Penal de Haia]; isso pode ser interpretado como um 'sinal profético', talvez o único, da tendência da humanidade 'em direção ao melhor', segunda a expressão kantiana". ${ }^{105}$ Conclui o ensaio em questão afirmando que direitos humanos, democracia e paz são três momentos necessários dentro do mesmo movimento histórico: sem o reconhecimento e a defesa efetiva dos direitos humanos, não há democracia; sem democracia, não existem condições mínimas para resolver os conflitos entre indivíduos, entre grupos e entre essas grandes comunidades tradicionalmente rebeldes e tendenciosamente autocráticas que são os Estados - e mesmo quando são democráticos em relação aos seus cidadãos.

105 Obra cit., pág. 197 


\section{Considerações finais}

O objetivo da Ciência Política é estudar a política tal como ela é. O objetivo da Filosofia Política é olhar a política como ela deveria ser. Mais do que isso: a missão da Filosofia Política é construir e reconstruir os raciocínios que giram em torno das questões relativas ao poder. O objetivo da Ciência Jurídica é estudar as normas e os ordenamentos como eles são postos, livre de juízo ideológico. O objetivo da Filosofia do Direito é dizer como deve ser o direito, para se ter justiça.

Ao ler Bobbio, repensamos as lições dos pensadores clássicos e dos modernos, cujos ensinamentos nos chegam de forma didática, facilitando a assimilação. Isso se torna evidente pela leitura, sobretudo, dos Capítulos 2 e 3 dessa Dissertação, nos quais, pelas lentes do professor de Turim - e puxado pelas suas mãos - fazemos uma profunda incursão no pensamento político clássico e nos conceitos acerca das formas de governo.

Mas também é perceptível pela leitura dos demais capítulos, onde fica expresso - ao menos, foi esse o meu intuito - o rigor analítico, a clareza e a capacidade de contextualização histórica com que Bobbio procura passar os seus ensinamentos. Bobbio foi, na verdade, antes de qualquer outra coisa, um grande mestre, dotado de uma singular capacidade de transmitir os seus conhecimentos, em áreas do reconhecidamente abrangentes como a Filosofia Política e a Filosofia do Direito.

José Ferández Santillán afirma em Norberto Bobbio, o Filósofo e a Política - Antologia que, com base numa sólida formação acadêmica e uma vida pessoal sossegada, Bobbio pôde desenvolver uma visão penetrante do período que lhe coube viver, mas sua perspectiva não se limita a esse lapso de tempo e, "sem exagero", cobre a maior parte da cultura ocidental". ${ }^{106}$ Criado em meio ao fascismo que combateu e do qual sofreu perseguição, construiu sua obra acadêmica e sua participação no debate político italiano e europeu nutrindo uma postura de desconfiança em relação à política demasiadamente ideologizada. $\mathrm{O}$ próprio Bobbio reconheceu que o conjunto de seus textos poderiam suscitar a

${ }^{106}$ Obra cit., pág. 15. 
imagem de "labirinto" descrita por alguns de seus comentaristas como Luigi Bonanate, Michelangelo Bovero e mesmo Santillán. Mas, se o mergulho em sua produção intelectual leva a um labirinto, devido ao volume e à abrangência, as saídas estão sempre indicadas na clareza dos conceitos apresentados.

Celso Lafer assinala, no prefácio de A Teoria das Formas de Governo, que "Bobbio não ignora as dificuldades da democracia, porém, insiste nos seus méritos seja porque examina os problemas do Estado, vendo como questão de fundo das formas de governo a liberdade, seja porque, coerentemente com esta perspectiva, realça que as normas podem ser criadas de dois modos: autonomamente pelos seus próprios destinatários ou heteronomamente por pessoas diversas dos destinatários. E fica evidente a razão pela qual Bobbio prefere a democracia enquanto processo de nomogênese jurídica, posto que se trata de uma forma de governo que privilegia uma concepção ascendente de poder graças à qual a comunidade política elabora as leis através de uma organização apropriada da vida coletiva". ${ }^{107}$

Que pode haver lacunas em sua vasta obra, não restam dúvidas. Giuseppe Tosi aponta, em "10 Lições sobre Bobbio", a que talvez seja a maior delas. Se o pensador de Turim criticava Marx por não ter se dedicado a uma Teoria do Estado (a não ser, segundo ele, que subliminarmente), a Bobbio talvez tenha faltado uma reflexão sobre o econômico. E afirma:

"Assim como na Teoria Marxista falta uma doutrina do Estado, na teoria de Bobbio falta uma teoria do lugar da economia (capitalista, conceito muito pouco usado por Bobbio e menos ainda analisado) na democracia. Sua teoria é eminente e exclusivamente política; ela não avança no terreno da economia e, quando o faz, encontra impasses e aporias que não consegue superar." 108

A resposta de certa forma pode ser encontrada naquilo que Tosi chama de "moderatismo bobbiano": na democracia não seria possível fazer saltos qualitativos, ou seja, revolucionários, mas somente reformas gradativas. E o que pode acontecer - e talvez tenha mesmo acontecido, segundo Tosi - é um compromisso entre economia capitalista e democracia liberal, por meio da

\footnotetext{
${ }^{107}$ BOBBIO, Norberto. A Teoria das Formas de Governo. Brasília (DF), Editora Universidade de Brasília, 10a Edição, pág. 24

108 TOSI, Giuseppe. 10 Lições sobre Bobbio. São Paulo (SP), Editora Vozes, 2016.
} 
experiência europeia. Essa seria, na visão de Bobbio, a máxima síntese possível a convergência suprema.

Afirma Bobbio que o modo como o poder é conquistado não é irrelevante para a forma pela qual ele será exercido, estabelecendo desta maneira, o nexo entre legalidade enquanto qualidade dos procedimentos e a legitimidade enquanto título para o exercício do poder. Ensina o professor de Turim em seu Dicionário de Política, que na tipologia dos sistemas políticos, são chamados de autoritários os regimes que privilegiam a autoridade governamental e diminuem de forma mais ou menos radical o consenso, concentrando o poder político na mão de uma só pessoa ou de um só órgão e deixando em posição secundária as instituições representativas da "sociedade civil".

Eis aí uma enunciação característica do pensador que vai sempre em direção ao conteúdo, quando busca estruturar conceitos, não se detendo na forma. E é esse pensador que vai se auto-denominar (ou se reconhecer como) um liberalsocialista ou socialista-liberal, mesmo admitindo a ambiguidade que o termo encerra. E é ele próprio quem faz a exegese dessa ambiguidade em ensaios como "Tradição e herança do liberalismo social"109, uma tarefa, vale dizer, que indiretamente expõe o seu caráter convergente, o seu moderatismo, a sua busca pela conciliação por meio das aproximações sucessivas.

Afirma Bobbio, de forma categórica, que entre os diversos tipos de socialismo listados por Marx e Engels no Manifesto comunista, o socialismo liberal de fato não aparece. Esclarece, contudo, que outras obras não deixam dúvidas quanto à existência de um liberal socialismo alemão, entre elas, Der deutsche Sozialliberalismus (1917-1933), bem como ao uso político de sua fórmula.

Prossegue o referido ensaio discorrendo sobre os possíveis pontos de contato e, sobretudo, de confronto entre socialismo e liberalismo. Ampara-se em outra obra - As origens do socialismo liberal, de Renato Treves - para descrever este possível social-liberalismo como um movimento, sem partido, que acredita na "evolução de uma sociedade sem dominação e exploração de uma classe sobre outra, de uma sociedade que garanta nos limites do meio econômico todas as

109 SANTILlÁN, José Fernandez. Norberto Bobbio, o Filósofo e a Política/Antologia. Rio de Janeiro (RJ), Contraponto Editora, 2016, pág. 505. 
liberdades políticas e privadas do indivíduo". ${ }^{110}$ Porém, como é característico de suas aproximações sucessivas, na busca de uma síntese a qual se impõe como exercício intelectual obrigatório inerente ao seu caráter moderador, refaz a trajetória histórica dos dois conceitos antagônicos. E a partir deste ponto afirma, de forma didática:

"É verdade que toda a história do pensamento político do século XIX, e em particular do século XX, poderia ser narrada como a história do contraste entre o liberalismo e o socialismo, pelo menos em três níveis, a começar pelo mais alto (que é o ideológico), e terminando no mais baixo (o dos movimentos), depois de passar pelo intermediário (o das instituições)". ${ }^{111}$

Citando Ludwig von Mises, com a sua obra crítica Socialismo, e Friedrich A. von Hayek, que nomeou o socialismo como "o caminho para a servidão", Bobbio afirma que não há nenhuma grande dicotomia no campo das ciências sociais em que liberalismo e socialismo não se coloquem em lados opostos. Vai além, afirmando que, quando o primeiro se coloca de um lado, o segundo parece não poder deixar de situar-se no outro. E então dá como exemplos: primazia da esfera privada ou da pública; propriedade individual ou coletiva; burguesia como sujeito dominante ou proletariado como sujeito histórico alternativo; direita ou esquerda; visão individualista do homem ou visão organicista da sociedade; atomismo ou holismo; sociedade ou comunidade; o indivíduo antes ou depois da sociedade.

Crítico do liberalismo que transforma toda relação humana em utilitarismo (em intercâmbio utilitarista, de caráter mercadológico), Bobbio tenta convergir das séries intermináveis de antíteses dos dois lados que se opõem em termos filosóficos, econômicos e políticos para uma síntese, afirmando que o confronto está fadado a se atenuar até desaparecer, transformando o oxímoro em uma síntese, à medida que nos afastamos dos movimentos socialistas influenciados pelo marxismo. Recorrendo aos seus conhecimentos das obras políticoeconômicas clássicas, Bobbio afirma que a confluência das duas correntes de pensamento fica mais clara se deslocarmos a análise para a Inglaterra.

"A história do liberal-socialismo poderia ter sido iniciada por John Stuart Mill, embora ele seja um dos maiores expoentes do liberalismo. São

\footnotetext{
110 Obra cit., pág. 506.
}

111 Obra cit. pág. 506. 
conhecidas as suas simpatias pelas ideias socialistas, em especial nos últimos anos de vida. Entre os diversos fragmentos de seus textos mais frequentemente citados neste sentido, um dos que têm maior significado é a carta a K.D.H. Rau de 20 de março de 1852, na qual se lê: 'parece-me que o propósito principal da melhora social deve ser preparado mediante a educação para uma sociedade que combine a máxima liberdade pessoal com a distribuição justa dos frutos do trabalho, que as atuais leis sobre a propriedade não permitem alcançar'." 112

Bobbio destaca que, para indicar a superação, "como diriam nossos filósofos", da antítese histórica entre o liberalismo e o socialismo, Mill utiliza o termo "combinar", que, além de revelar sua conduta empirista, segundo o pensador de Turim, implicaria, do ponto de vista pragmático, um embate no campo político entre princípios liberais e princípios socialistas. Mas trata-se de um embate no campo político, não revolucionário. E a síntese progressiva dar-seia por meio de um trabalho permanente visando garantias de direitos individuais e políticos compatibilizados com avanços sociais indispensáveis a uma sociedade moralmente evoluída. O socialismo, visto desta forma, não seria o avesso do liberalismo, mas, sim, o seu desenvolvimento e superação. Essa concepção elimina o determinismo histórico, eminentemente marxista. Aqui não cabe um determinismo histórico.

O "socialismo liberal" sobre o qual Bobbio discorre teria como origem o entendimento de que os dois "ismos" não constituem uma antítese, um oxímoro; portanto, a sua integração prática deve ser entendida como uma síntese, "hegelianamente definida como um terceiro momento de uma antítese negada e superada". ${ }^{113}$ Afirma Bobbio, no seu esforço convergente:

"Marx detectou com clareza a primazia do poder econômico sobre os outros poderes - precisamente da base estabelecida pelas relações econômicas com referência à superestrutura ideológica e política. Todavia, o remédio que ele propôs, ou que os movimentos políticos dele decorrentes procuraram aplicar, teve os efeitos perversos que todos vemos hoje em dia [em referência à supressão da liberdade na União Soviética e ao Leste europeu]. Foi justamente esse efeito perverso que, nos últimos anos, ressuscitou o ideal do socialismo liberal. Esse nasceu da necessidade de solucionar em nome do socialismo os efeitos práticos do liberalismo, que, com o desenvolvimento cada vez mais rápido e incontrolável da sociedade

112 Obra cit., pág. 508.

113 Obra cit. , pág. 513. 
industrial, desviou-se, nas sociedades mais industrializadas, para formas de opressão e escravização das massas." ${ }^{114}$

O texto em referência é do início da década de 1990. Num mundo ainda fortemente abalado pela polarização ideológica produzida por décadas de Guerra Fria, Bobbio, também tarimbado pelas acirradas disputas político-partidárias italianas, na qual se propunha e era reconhecido como um mediador isento, exercita a busca da convergência. Com este espírito e com inegável otimismo no progresso da humanidade, afirmava que a humanidade começava a deixar de lado os "ismos" para apenas falar de liberdade e igualdade, e que isso era o que realmente importava. Liberdade para todos os povos, com igualdade no tocante à distribuição de riquezas. Ainda que o primeiro problema remeta à doutrina liberal e o segundo, à doutrina socialista, ambos podem ser resumidos simplesmente no lema "Justiça e Liberdade".

\footnotetext{
${ }^{114}$ Obra cit., pág. 513.
} 


\section{8}

\section{Referências bibliográficas}

AGAMBEN, Giorgio. Estado de Exceção. São Paulo (SP), Fundação Editora da UNESP, 2004.

ARENDT, Hannah. Origens do Totalitarismo, São Paulo (SP), Companhia das Letras, 1989.

ARISTÓTLES. A Política. Rio de Janeiro (RJ), Ediouro/Coleção Universidade, 1985.

ARISTÓTELES. A Ética a Nicômaco. São Paulo (SP), Edipro, 2014.

BARBOSA, Alaor. O problema do positivismo - Norberto Bobbio e o Positivismo. Editora Universidade de Brasília, 2004.

BOBBIO, Norberto. A Era dos Direitos. São Paulo (SP), Editora Elsevier, 2004.

BOBBIO, Norberto. A Teoria das Formas de Governo. Brasília (DF), Editora Universidade de Brasília, 10a Edição.

BOBBIO, Norberto. Democracia e Segredo. São Paulo (SP), Editora UNESP, 2015.

BOBBIO, Norberto. Dicionário Político. Brasília (DF), Editora Universidade de Brasília, 1983.

BOBBIO, Norberto; MATTENTI, Nicola; PASQUINO, Gianfranco. Dicionário Político. Brasília (DF), Editora Universidade de Brasília, 1983

BOBBIO, Norberto. Direita e Esquerda. São Paulo (SP), Editora UNESP, 1995.

BOBBIO, Norberto. Direito e Estado no Pensamento de Emmanuel Kant. Brasília (DF), Editora Universidade de Brasília, 1984.

BOBBIO, Norberto. Direito e Poder. São Paulo (SP). Editora UNESP, 2007.

BOBBIO, Norberto. Estado, Governo e Sociedade - Para uma teoria geral da Política. São Paulo (SP), Paz e Terra, 1997/6a Edição.

BOBBIO, Norberto. Ensaios sobre Gramsci. Brasília (DF), Editora Universidade de Brasília, 2001.

BOBBIO, Norberto. Igualdade e Liberdade. Brasília (DF), Editora Universidade de Brasília, 2001. 
BOBBIO, Norberto. Jusnaturalismo e Positivismo Jurídico. São Paulo (SP). Editora UNESP, 1996.

BOBBIO, Norberto. Liberalismo e Democracia. São Paulo (SP), Edipro, 2017.

BOBBIO, Norberto. Nem com Marx, nem contra Marx. São Paulo-SP, Editora UNESP, 2004.

BOBBIO, Norberto. Positivismo Jurídico - Lições de Filosofia do Direito. São Paulo (SP), Ícone Editora, 2006.

BOBBIO, Norberto. Teoria do Ordenamento Jurídico. Brasília (DF), Editora Universidade de Brasília, 10a Edição.

BOBBIO, Norberto. Teoria da Norma Jurídica. Brasília (DF), Editora Universidade de Brasília, 2001.

HOBBES, Thomas. O Leviatã ou matéria, forma e poder de um Estado Eclesiástico e Civil, São Paulo, Editora Victor Civita, 1983.

KANT, Immanuel. A Metafísica dos Costumes/A Doutrina do Direito. São Paulo, Edipro, 2003.

KELSEN, Hans. A Teoria Pura do Direito. São Paulo-SP, Martins Fontes, 1999.

LAFER, Celso. Norberto Bobbio: Trajetória e Obra. São Paulo-SP, Editora Perspectiva, 2013.

LOCKE, John. Segundo Tratado sobre Governo. São Paulo-SP, Editora Abril/Coleção Os Pensadores, 1983.

MAQUIAVEL, Nicolau. O Príncipe, Rio de Janeiro-RJ, Bibliex, 1998.

MELLO, Nilson Vieira Ferreira de. Brasil tão bom quanto o nosso voto - Ensaios sobre Estado, governo e sociedade. Rio de Janeiro-RJ, Edição de Autor, 2008.

MONTESQUIEU, Charles Louis de Secondat. Do Espírito das Leis. Editora Abril/Coleção Os Pensadores, 1985.

PLATÃO. Diálogos III - A República. Rio de Janeiro-RJ, Ediouro/Coleção Universidade, 1985. 
PERELMAN, Chaïm. Ética e Direito. São Paulo-SP, Martins Fontes, 1999.

ROUSSEAU, Jean Jacques. Do Contrato Social. São Paulo (SP), Editora Abril/Coleção Os Pensadores, 1983.

SANTILLÁN, José Fernandez (organizador). Norberto Bobbio, o Filósofo e a Política/Antologia. Rio de Janeiro (RJ), Contraponto Editora, 2016.

SHMITT, Carl. O Guardião da Constituição, Belo Horizonte (MG), Del Rey, 2007.

TOSI, Giuseppe. 10 Lições sobre Bobbio. São Paulo (SP), Editora Vozes, 2016.

VIEIRA, José Ribas. Teoria do Estado - A Regulação Jurídica. Rio de Janeiro-RJ, Editora Lumen Juris, 1995.

WEBER, Max. Ciência e Política. São Paulo-Sp, Ed. Cultrix, 1993. 